\title{
PARATEXTUALIDADE E TRADUÇÃO: A PARATRADUÇÃO DA LITERATURA INFANTIL E JUVENIL ${ }^{1}$
}

\author{
José Yuste Frías* \\ Universidade de Vigo \\ Tradução de: Gisele Tyba Mayrink Orgado**
Universidade Federal de Santa Catarina
}

Resumo: O objetivo deste artigo é provar a aplicação empírica, sociológia e discursiva da noção de paratradução como uma ferramenta metodológica adequada ao estudo de elementos paratextuais na tradução em geral, e, particularmente, na Tradução da Literatura Infantil e Juvenil (TRALIJ).

* Doutorou-se em Filosofia e Letras (Filologia Românica) pela Universidad de Zaragoza, Espanha, em 1997. Atualmente é professor Titular no Departamento de Tradução e Linguística da Faculdade de Filologia e Tradução da Universidade de Vigo, Espanha. Principal pesquisador do Grupo de Investigación de Referencia Traducción \& Paratraducción (T\&P), criou, coordena e edita desde 2008 três programas Web-TV de divulgação científica dedicados ao universo da tradução: Zig-Zag, EXIT e Píldoras T\&P. Especialista em símbolo e imagem em tradução, suas publicações são centralizadas nos campos da tradução de histórias em quadrinhos, livros infantis e tradução publicitária. Teórico da tradução, é o criador da noção de "Paratradução", uma nova terminologia tradutológica que abre novas perspectivas teóricas, didáticas e profissionais nos Estudos da Tradução. Vigo, Espanha. E-mail: jyuste@uvigo.es

** Possui graduação em Comunicação Social, com especialização em Jornalismo, pela Faculdades Integradas Hélio Alonso (FIHA), no Rio de Janeiro. Mestrado, em 2010, e doutorado, em 2014, em Estudos da Tradução pela Universidade Federal de Santa Catarina (UFSC). Atualmente é pesquisadora sobre os Estudos Japoneses no Brasil, nas áreas de língua, literatura e cultura japonesa. E-mail: gisele.orgado@gmail.com 
O artigo inicia com uma visão panorâmica da investigação em TRALIJ, continua com uma extensa e atualizada introdução teórica sobre a noção de paratradução, um neologismo nos estudos da tradução introduzido pelo autor na criação do grupo de pesquisa Tradução \& Paratradução da Universidade de Vigo. Prossegue com a descrição detalhada, a análise pormenorizada e o estudo crítico completo do corpus constituído por um trabalho efetivo de TRALIJ solicitado pela editora espanhola Imaginarium, que consistiu na tradução para o espanhol de dois livros infantis escritos em francês. Apresenta-se uma leitura e a interpretação da simbologia das listras utilizada no desenho tipográfico da letra dos títulos dos dois livros da edição francesa, com a finalidade de comprovar como se realizou, na edição espanhola, a paratradução de tal tipografia. O artigo finaliza apontando a premente necessidade de aceitar na prática da tradução uma ética do limiar, implícita na própria noção de paratradução, com o intuito de estabelecer, de uma vez por todas, um diálogo permanente entre tradutores e editores, a fim de garantir que nenhuma tradução seja publicada sem sua devida paratradução.

Palavras-chave: Texto_Paratexto. Tradução_Paratradução. Literatura Infantil e Juvenil (LIJ). Örtotipografia. Simbologia da listra.

\title{
PARATEXTUALITY AND TRANSLATION: PARATRANSLATION IN CHILDREN'S LITERATURE
}

\begin{abstract}
The aim of this contribution is to prove the empiric, sociologic and discursive usefulness of the notion of paratranslation as a proper methodological tool for the study of paratextual elements in translation in general, and specifically, of Children's Literature Translation. The contribution opens with an overview of the investigation in Children's Literature Translation, continues with an extensive and updated theoretical introduction about the notion of paratranslation, a new term in translation studies coined by the Translation and Paratranslation research group at the University of Vigo. Proceeds with a detailed description, an elaborated analysis and a complete critical study of the corpus constituted by a real work of Children's Literature Translation requested by the Spanish publisher Imaginarium, which consisted of the translation into Spanish of two children's books written in French. It presents the reading and interpreting of the symbolism of stripes used in typographic design of the title letter of the two books in French edition, in order to demonstrate how the paratranslation of such typography was conducted in the Spanish edition. The article is concluded by pointing out the urgent need to accept an ethical threshold in the practice of translation, implicit in the notion
\end{abstract}


of paratranslation, with the purpose of establishing, once and for all, a permanent dialogue between translators and editors, to ensure that no translation is published without its corresponding paratranslation.

Key-words: Text_Paratext. Translation_Paratranslation. Children's Literature. Orthotypography. Symbolism of stripes.

Desde o seu surgimento no século XVIII, a produção literária voltada para o público infantil, impulsionada por certas correntes culturais e ideológicas, nunca deixou de ser traduzida em diferentes países da velha e da nova Europa. Circunscrito no tempo e no espaço da época da Ilustração (Século das Luzes), o nascimento da literatura infantil depende completamente da existência de uma sociedade burguesa e letrada que queria expressar por escrito o descobrimento, a apropriação e a sacralização da infância.

As origens da literatura para crianças remontam à época do Iluminismo, quando o nascimento de uma nova pedagogia situou a criança no centro dos interesses dos filósofos, suscitando a criação de produções especialmente concebidas em função do que se supunha fazer parte de suas necessidades afetivas e de suas capacidades intelectuais. $\mathrm{O}$ desenvolvimento desse novo gênero se efetivou à aura de correntes culturais e ideológicas que influenciaram toda a Europa e incitaram escritores de todos os países a compor, para as crianças, livros com finalidades pedagógicas (COLIN, 1992, p. 2-3).

Atualmente, os livros de Literatura Infantojuvenil (doravante LIJ) tornaram-se uma necessidade pedagógica tão evidente e absoluta como os rudimentos da escola primária: ler, escrever e contar. Educadores, pais, pesquisadores, autores e até mesmo as próprias crianças podem pensar que se há a necessidade de aprender a ler, escrever e contar, é para descobrir a imensa produção de livros, estórias, romances, história em quadrinhos, manuais, coletâneas e enciclopédias, publicadas e direcionadas de acordo com a idade e até o sexo de um público que varia desde o mais amável bebê ao jovem não adulto. Estamos presenciando uma generalização em 
massa das atitudes e formatos escolares no seio da vida social e cultural: tudo se torna pedagógico em um abrir e fechar de olhos. A “didática" embutida em qualquer atividade infantil ou juvenil busca transformar qualquer instante de pura experiência vital em momento educativo para transformar, deste modo, as experiências humanas em autêntico "capital cultural” que se pode editar e vender em escala internacional graças à tradução.

A LIJ é um dos campos de estudo mais fecundos no mundo da tradução. Traduzir a enorme quantidade de livros que se deseja publicar para crianças e jovens é uma das fatias mais cobiçadas do mercado profissional da tradução. Como as duas faces de uma mesma moeda, os livros infantis e juvenis são, por um lado, um bem cultural, e por outro, um produto comercial de grande consumo. Transformada em uma autêntica indústria com um volume de vendas cada vez maior, a LIJ está submetida a todas as pressões comerciais possíveis, com tudo o que isso implica ao se realizar qualquer estudo.

Integrados ao sistema dos mercados de consumo, os objetos culturais se submetem à aceleração de uma produção que os torna cada vez mais efêmeros. Logo, além de desencorajar posicionamentos críticos, os afastamentos temporais necessários a seu estudo acabam tornando caducos os proveitos que os leitores poderiam retirar deste último (PERROT, 1999, p. 14).

\section{Infantil ou Juvenil?}

Elaborada pelos próprios adultos, a ideia da infância é uma representação mental de um período vital muito específico da vida humana. A tradução da literatura infantil e sua recepção como tal, isto é, como produto traduzido para um público muito específico as crianças - reproduz uma imagem da infância forjada pelo adulto à sua própria imagem e semelhança. Os tradutores acrescentam às suas traduções parâmetros culturais, sociológicos e antropológicos 
muito específicos. No caso da literatura infantil, nossa representação atual da própria criança, ou seja, a imagem de "quem ainda não pode falar" (do latim infans), influencia sobremaneira na hora de traduzir livros infantis, uma vez que direciona, consciente ou inconscientemente, todo nosso trabalho. É frequentemente comum esquecer que a imagem que se tem da infância hoje em dia não é mais a mesma que se tinha em outros tempos: a mentalidade da sociedade medieval, por exemplo, não considerava a infância como vem sendo considerada na época moderna. Antes do século XVIII a criança não era uma entidade diferente de um adulto e, consequentemente, não se reconheciam necessidades especiais ou distintas das de um adulto. Durante a Idade Média, as crianças participavam ativamente na sociadade desde muito cedo (entre 10 e 13 anos) porque havia necessidade de que trabalhassem. Qualquer criança que sobrevivesse aos primeiros anos de vida não permanecia criança por muito tempo e logo era obrigada a fazer parte do mundo adulto. Consequentemente, as traduções de um texto onde aparece o tópico medieval de puer senex - a criança sábia - (cf. YUSTE FRÍAS, 1993), ou outro cujo protagonista recebe uma iniciação que o transforma em renatus in novam infatiam - um homem novo renascido em uma nova infância - não implicará a mesma leitura e interpretação do conceito de infância que se encontram implícitas na tradução de um texto escrito ao longo do século XX, ou durante este século XXI, para o contemporâneo puer aeternus - a criança eterna, a criança divina - popularizado incessantemente pela própria produção editorial da literatura infantil em suas diversas adaptações do chamado "complexo de Peter Pan".

$\mathrm{O}$ século $\mathrm{XX}$ é caracterizado pela utilização quase obsessiva do conceito de infância: questões sobre problemas psicológicos, físicos e sexuais da criança não deixam de preocupar os adultos. O período da infância é considerado o período mais importante na vida de alguém, e o comportamento de um adulto é frequentemente explicado por suas experiências infantis. Mas tal percepção de infância é com- 
pletamente diferente da perspectiva cultural que prevalecia 200 anos atrás - não havia, então, o conceito de infância como o conhecemos hoje (SHAVIT, 1989, p. 131).

Tanto a denominação "Literatura Infantil y Juvenil" em espanhol, como littérature d'enfance et de jeunesse em francês e às vezes até mesmo Children's Literature em inglês ou Kinderliteratur em alemão, são denominações demasiadamente extensas tendo em vista que englobam, em maior ou menor grau, dois tipos de receptores bem distintos: as crianças e os jovens. Comparar a infância e a juventude adolescente significa renunciar a atribuir a cada uma dessas etapas da vida humana a especificidade psíquica que a própria produção editorial pretende que lhe seja atribuída. Considero que ao colocar no mesmo pacote a infância e a juventude adolescente na própria denominação de LIJ, o próprio conceito perde o seu sentido de infância, uma vez que se dilue em uma espécie de nebulosidade comercial onde se edita e se publica muito mais para um público bem mais abrangente e mais rentável que o público infantil das crianças: os jovens. Não se pode esquecer que, ao contrário do que ocorre no caso dos livros que se editam para as crianças, não são os pais que compram os livros que se editam para os jovens. São os próprios jovens quem decidem comprar seus livros, convertidos em um produto comercial do mais vasto e rico consumo juvenil.

Aparentemente, o adjetivo "infantil" em uma nomenclatura exclusiva como em "literatura infantil" implica em certo sentido pejorativo que colocaria o substantivo "literatura" em uma posição inferior, popular, menor (Por isso ele seria adequado aos menores?). Por outro lado, no uso generalizado da denominação global LIJ, a literatura infantil seria tão somente a primeira etapa do conjunto: aquela em que se edita livros para crianças que sejam realmente crianças, ou seja, que ainda não sejam adolescentes. Embora tenha se publicado muito desde $1978^{2}$, de modo que seu status não é considerado "inferior" ou "menor" que qualquer outra pesquisa sobre o mundo "adulto", as pesquisas em LIJ ainda são consideradas no sé- 
culo XXI como "periféricas e insignificantes", assim como afirma, continuamente, a própria Zohar Shavit (1994; 2003).

\begin{abstract}
No atual mundo acadêmico pesquisas sobre a literatura infantojuvenil não são legalizadas de fato, não são muito respeitadas, e quando aceitas, são tidas como um campo de pesquisa periférico e insignificante. Em suma, a pesquisa sobre literatura infantojuvenil hoje padece de um status inferior. E se nada for feito a respeito, continuará assim por muitos anos (SHAVIT, 1994, p. 4; SHAVIT, 2003, p. 32).
\end{abstract}

O fato de que, sob muitos aspectos, a LIJ pode se tornar um tipo de paraliteratura diante da literatura canônica ou supostamente "séria" dos adultos, não significa que haja qualquer justificativa para não considerá-la como digna de ser tomada como objeto de pesquisa científica. Realizar o estudo e a crítica da tradução de livros e outras publicações paraliterárias infantis e juvenis não é, de modo algum, algo que possa ser considerado uma futilidade. Pelo contrário, ao se editar traduções para crianças e jovens, decidir o que se traduz, quem traduz, para quem, como, quando, onde, por quê, para quê e com que meios, é uma operação muito delicada na qual uma sociedade se responsabiliza por desenvolver, ou não, novos leitores no futuro.

\title{
2. Literatura e paraliteratura!
}

A questão da intencionalidade, o que significa que o livro foi escrito para que as crianças e os jovens o leiam, parece ser um dos parâmetros mais utilizados ao se explicar o que é e o que significa a literatura infantil ou juvenil. Todavia, desde o nascimento da LIJ sempre existiu a prática editorial de publicar obras para crianças a partir de recriações de obras destinadas, a princípio, para os adultos. Este foi o caso de muitas obras que hoje são consideradas clássicos 
"internacionais" da LIJ: As aventuras de Huckleberry Finn ou Tom Sawyer de Mark Twain, As viagens de Gulliver de Swift ou Moby-Dick de Herman Melville ${ }^{3}$, por exemplo, foram obras "condenadas" a existir como estórias que não integrassem a "literatura séria" devido a seus conteúdos altamente subversivos. Atualmente, mesmo alguns fenômenos de adultos fazem parte da cultura infantil como, por exemplo, os temas musicais do grupo Spice Girls (mencionado inclusive pela própria Riita Oittinen) que nos anos 90 do século XX foram cantarolados em um inglês macarrônico e até mesmo encenados em festas de conclusão de escola por muitas meninas, e não tão meninas assim, do primeiro mundo para um público não anglófono. Concordo plenamente com a visão do vasto corpus então proposta pela mencionada pesquisadora finlandesa ao definir o que ela chama, de forma muito apropriada, de "literatura para crianças", e não "literatura infantil" ou mesmo "literatura da infância" (cf. OITTINEN, 2000 , cap. IV). Tendo em vista que nas atuais políticas editoriais da LIJ parece não haver fronteira alguma entre o circuito adulto e circuito criança/jovem nas diversas criações literárias e paraliterárias, pode-se concluir perfeitamente que a LIJ pode vir a ser qualquer coisa que a criança ou o jovem leia, veja ou escute.

Exatamente porque hoje em dia a LIJ cruza sem problema algum o limiar entre bem cultural e produto de consumo que considero como LIJ não somente todo material que aparece no catálogo de livros infantis e juvenis de uma editora, mas também tudo o que se escreve para as crianças e jovens sem qualquer intenção literária, isto é, todas as produções paraliterárias impressas, audiovisuais e de multimídia que não adotam o formato editorial do livro tradicional. Portanto a TRAdução da Literatura Infantil e Juvenil (doravante TRALIJ) não se limita apenas à leitura, interpretação e tradução dos livros infantis e juvenis. Incluso em um levantamento do corpus de pesquisa em TRALIJ não apenas qualquer produção paraliterária impressa, regular ou não, com ou sem ISSN ou ISBN, direcionada às crianças e aos jovens, como também qualquer produção paraliterária audiovisual ou de multimídia (em formato VHS, DVD, CD-ROM ou mesmo on-line) que a criança ou o jovem vê, 
observa, lê, ouve ou escuta e lhe pareça interessante ou simplesmente divertido, ainda que não sejam objetos de pesquisa. A partir desta perspectiva paraliterária abrangente, a grande variedade de suportes analógicos e digitais da TRALIJ com a que se depara um tradutor do século XX pode se tornar esmagadora.

Os propósitos traçados pelo TRALIJ são bastante desconhecidos pelo grande público; as publicações paraliterárias impressas em que aparecem personagens de quadrinhos criados por multinacionais da distribuição para os clubes infantis dos grandes centros comerciais nos quais são permitidos autênticos espaços de serviço público de "berçário" para que os pais possam deixar suas crianças enquanto se dedicam às compras semanais no centro comercial: penso, por exemplo, nos clubes Rik \& Rok de Jumbo/Alcampo/ Auchan em Portugal/Espanha/França. Uma gama paralela de produtos de consumo pensados para os consumidores infantis, o clube infantil bem como o nome que se utiliza para intitular a publicação impressa - a Revista do clube Rik \& Rok - que toda criança sócia do clube recebe trimestralmente em sua casa, foi criada em 1996 em Portugal. A apresentação original do website português do clube Rik \& Rok possui animações em flash que não se encontram na tradução multimídia das versões espanhola e francesa. Passeios virtuais pela website dos clubes Rik \& Rok português ${ }^{4}$, espanhol ${ }^{5}$ ou francês ${ }^{6}$ são a prova visível, audível e até mesmo "palpável" de que os mesmos personagens, Rik \& Rok, podem traduzir, em rede, imaginários infantis totalmente diversos a partir da página inicial de cada filial da multinacional Auchan.

Um volume considerável de TRALIJ é dado pelos compromissos que se tem com a tradução publicitária de grandes empresas multinacionais. Refiro-me às publicações publicitárias impressas de determinadas multinacionais de fast-food que apresentam em papel e papelão as aventuras de personagens infantis ao mesmo tempo em que estreiam nas telas das salas de cinema. Obviamente estou pensando na produção em série de todos esses descansos para copos, embalagens de alimentos, cartazes e faixas dos Happy Meal que a empresa McDonald's ou o próprio Ronald 
McDonald apresentam às crianças em idiomas do mundo inteiro, a cada vez que a empresa Walt Disney lança uma nova produção cinematográfica para crianças. Filmes infantis cujas diversas dublagem e legendas, certamente, constituíram a encomenda de tradução audiovisual e multimídia.

Os compromissos assumidos pelo TRALIJ com relação aos videogames infantis e juvenis são muito atraentes, sejam educativos ou nem tanto, baseados nos filmes lançados em telas de cinema. Videogames que estão disponíveis no mercado muito antes da era digital atual, pelo menos desde o tempo de E.T., o grande sucesso fílmico de Steven Spielberg, que em 1983 serviu de inspiração para um videogame, o Atari 2600. Desde os anos 80 a estreita relação existente entre Hollywood e o mundo dos videogames tem sido incorporada no progressivo aumento do volume de encomenda de tradução multimídia considerando as oportunidades de negócios por trás da exploração de filmes em tela que não sejam a "tela grande", que estrearam graças à tecnologia digital. Guerra nas Estrelas, O senhor dos anéis, Homem-Aranha, Matrix ou Harry Potter são algumas das produções juvenis de Hollywood que acabaram se transformando em videogames no mundo inteiro graças à tradução multimídia.

Outro grande desconhecido do grande público como produto traduzido é apresentado pelo campo da TRALIJ composto pelas produções impressas editadas por multinacionais de animação ao explorar suas produções audiovisuais com a tradução de cartões e cartas que afixam em papel, papelão ou plástico a imagem que antes estava em movimento. Dois exemplos: o primeiro, o das traduções em espanhol das cartas de $\mathrm{Yu}$-Gi-Oh! (Konami Corporation) que as crianças da Espanha trocam na escola, pessimamente redigidas em espanhol, cheia de erros ortográficos e transbordando anglicismos; o segundo exemplo seriam todos os nomes próprios dos personagens das cartas de Pokémon (Nintendo/Creatures Inc.) que, apesar de serem nomes próprios de ficção que conotam muito mais do que designam, nunca se traduzem e mantêm literalmente a grafia anglófona original em Lamincards Collection. 
E o que dizer a respeito do corpus da TRALIJ composto pelo repertório de canções tradicionais infantis com versões que variam de acordo com as línguas e as culturas? Jingle Bells, Vive le vent, Navidad Navidad e Bate o Sino, por exemplo, são canções que têm as mesmas notas musicais, porém não são cantadas com a mesma letra no mundo inteiro, durante este período do ano em que cada adulto gostaria de voltar a ser criança. Mas não há necessidade que as canções tradicionais sejam ouvidas para que sejam traduzidas. Muitos textos com imagem fixa, como o caso dos livros infantis, também possuem "som e ritmo" quando nestes se pode ler alguma referência a letras e músicas de canções tradicionais infantis: a música apresentada no papel é audível ainda que mentalmente e faz parte da emotividade da situação de ler para traduzir.

Não poderia deixar de citar nesta breve enumeração dos compromissos da TRALIJ o considerável volume que envolve tudo o que uma criança ou um jovem possa ouvir, escutar, ver e observar nas séries de televisão que aparecem nas grades de programação infantil e juvenil de determinados canais temáticos oferecidos em pacotes digitais abertos ou pagos. Música e televisão. Tradução audiovisual e multimídia. Muito poderia ser escrito a respeito das traduções e não traduções das melodias de todos esses desenhos animados que marcaram o ritmo de muitas infâncias diante de um simples aparelho de TV! Quem na Espanha não se lembra das letras sem tradução, isto é, em suas respectivas línguas originais, das melodias das séries de desenho animado como Vicky el Vikingo, Heidi ou Candy Candy?

\section{Texto e paratextos nos livros infantis: a iconotextualidade}

O livro infantil não se trata de algo novo, mas sua produção editorial nunca foi tão rica, variada e considerável como agora. Nos livros infantis os paratextos são mais importantes que o próprio texto. E digo paratextos, no plural, porque existe uma grande quantidade deles: desde o mais frequente (o peritexto icô- 
nico) até o mais divertido (o peritexto sonoro), passando pelo mais sofisticado (peritexto olfativo). É verdade, nos dias de hoje existem livros com aromas e não são poucas as possíveis dificuldades paratradutoras que se apresentam ao editar traduções de livros infantis com estes aromas incorporados a peritextos icônicos especiais que ativam peritextos olfativos altamente específicos, principalmente alguns odores em particular (tangerina, lavanda, bala, sabonete ou esterco) quando as crianças arranham as imagens com seus dedos ${ }^{7}$. Culturas diferentes implicam objetos simbólicos diferentes que possibilitem a (para)tradução dos diferentes odores. Os odores, como as cores, as imagens e os símbolos em tradução, não são de modo algum universais, também se traduzem e, sobretudo, se paratraduzem. Continuando com a enumeração das diferentes tipologias paratextuais dos livros infantis, não se pode esquecer as diversas formas adotadas pelas capas dos livros infantis ao apresentar o texto infantil no mundo editorial. De fato, o texto se torna em um livro infantil, sobretudo, graças ao desenho destas capas que podem adotar a forma desejada: existem, então, as capas em forma de casa, de árvore ou de travesseiro. O livro infantil intitulado L'étoile de Mimosa tem a forma de um travesseio. Livre oreiller tout doux, um "livro travesseiro", que pode ser lavado à máquina, mas não deve ser colocado na secadora, fabricado com algodão, desenhado na Itália, impresso na China e publicado pela editora francesa Quatre Fleuves (cf. GRÉGOIRE \& QUATRE FLEUVES, 2001). Diante de tamanha diversidade paratextual, um profissional de tradução pode se fazer as seguintes perguntas: As crianças às quais se destina sua tradução têm a mesma imagem da casa, da árvore ou de travesseiro que as formas adotadas nos paratextos das capas que apresentavam o texto de partida? E no caso particular do livro-travesseiro direcionado a crianças de "menos de 36 meses", por acaso todas as crianças do mundo dormem com travesseiro?

Mencionei anteriormente a expressão "menos de 36 meses" porque os editores da literatura infantil sentem a necessidade de dividir seu mercado em faixas etárias que pretendem abranger distintos 
níveis de leitura em função de um determinado período da infância. $\mathrm{Na}$ edição de livros infantis também podem ser encontradas expressões inversas do tipo "a partir de 2 anos" que, em minha opinião, apresentam falhas que podem chegar a ser estigmatizantes: a criança de 12 anos de idade que ler um livro "a partir de 8 anos", por exemplo, estaria fora do normal? Ou será que ao não ter tempo de observar o livro infantil, lê-lo e decidir se realmente seria conveniente à criança a quem deseja dá-lo, o adulto confia nesta espécie de "rotulagem" do livro antes de comprá-lo como faz quando compra outros produtos comerciais? Naturalmente estamos falando de livros e não de brinquedos, ou será que não seria o contrário? Afinal, todos sabemos que um bom livro no tem idade, nem tempo, nem limite. Portanto, a divisão por faixa etária é totalmente arbitrária já que estes supostos níveis de leitura dependem do desenvolvimento psicológico, intelectual e afetivo de cada criança-indivíduo. Todavia, não nego que tais divisões editoriais possam ser convenientes ao descrever os distintos tipos de livros infantis que encontra-se atualmente nas livrarias e outros pontos de distribuição ${ }^{8}$.

O livro infantil é um objeto, e não um gênero. A paratextualidade define a própria textualidade dos livros infantis. De fato, a diferença entre o livro infantil e outros campos de publicação da LIJ é o conjunto de características paratextuais peculiares que lhe atribuem um aspecto físico bem específico dentro do mercado editorial do livro: poucas palavras em poucas páginas e, sempre, muitas e muitas imagens dominando todo o espaço textual. Entretanto, a maior parte das crianças que está na faixa etária de leitores da produção editorial da LIJ não possui uma leitura autônoma ou, simplesmente, não sabem ler. Isto estabelece um acordo de leitura muito diferente da existente com relação às literaturas não infantis. Os livros infantis têm sempre um tipo de destinatário dúbio com contextos diferentes, mas complementares: de um lado, a criança que escuta o texto, contempla e toca a imagem, e de outro, o adulto que lê o texto em voz alta, e o dramatiza. Considerando o tipo de material resistente do suporte físico e o grau de manipulação do livro por parte da criança quando este cai em suas mãos, com ou 
sem um adulto por perto, poderíamos estabelecer a seguinte classificação tripartida gradual e arbitrária dos livros infantis:

1. Para começar poderíamos incluir em um primeiro grande grupo o tipo de livros infantis que recebem, em inglês, o nome de toy books e que gostaria de traduzir de duas formas: "livros brinquedos" por um lado, e "livro jogo", por outro. Os "LIVROS BRINQUEDOS" são todos os livros fabricados com diversos tipos materiais (papelão, tecido ou plástico) que permitem a leitura, a brincadeira, até mesmo na banheira (bathtub books) e que às vezes incluem mecanismos de reprodução de sons. São livros destinados a crianças menores, ávidas por descobrir, entrar em contato e interagir com tudo o que os rodeia para levar imediatamente à boca. É por esta razão que na concepção e na fabricação deste primeiro tipo de livros-objetos-brinquedos existem tantas normas legais de segurança e higiene dos brinquedos para crianças menores de 36 meses. À medida que cresce, a criança continua a tocar tudo e, ao mesmo tempo em que começa a falar, vai adquiriindo gosto por olhar e manipular os livros com e como seus pais. Este é o momento dos "livros jogos", ou seja, todos estes livros "animados" cujas páginas, de acordo com as necessidades, os gostos e, sobretudo, a capacidade de cada criança de destruí-lo com as mãos, ganham vida ao poder se abrir voluntária (flap books) ou involuntariamente (pop-up books), ou, ainda, ao puxar suas abas (pull-tab books);

2. Outros três tipos de livros infantis impressos em papel muito resistente ou mesmo em papelão constituem o segundo grupo. Em primeiro lugar, o que poderíamos chamar de "LIVRO CONCEITO" (concept book), que busca despertar a capacidade verbal e visual da criança com pequenos "estudos" dedicados às formas, às cores, às letras e aos números. Em segundo lugar, o "LIVRO DE LEITURA FÁCIL" (easy 
reader) pensado para quando chega o momento em que a criança gosta de ouvir estórias e descobrir personagens que lhe sejam familiares ou que lhe comovam. São projetados para que o aspecto verbal seja lido por um adulto, mas não o aspecto visual, em que o olhar da criança se movimenta de forma completamente autônoma. E em terceiro lugar, o "LIVRO SEM ALGUMAS PALAVRAS OU COM JOGOS” (wordless book) para que a criança comece a desenvolver o aspecto mais narrativo de sua capacidade verbal. São projetados com espaços em branco nos quais a criança aplica sua leitura visual das imagens que substituem as palavras não ditas pelo adulto enquanto lê em voz alta;

3. O terceiro e último grupo de minha classificação dos livros infantis incluiria os livros impressos em papel com uma resistência normal e no qual as palavras já adquirem uma importância considerável se comparadas à imagem, mas sem chegar a desprezá-la ou a substituí-la. A imagem continua a dominar todo o corpo textual. São livros editados para crianças que dominam a leitura de forma autônoma, sem qualquer ajuda de um adulto. As estórias contadas se traduzem em imagens que ilustram desde temas tradicionais da literatura oral (contos) ou os realismos mágicos de personagens antropomórficos ou teriomórficos, até estórias tão reais quanto as da própria vida (a morte, o câncer, a homossexualidade, a adoção e a Aids), passando por pequenas enciclopédias para crianças editadas em cores. Neste terceiro grupo estão publicados livros espetaculares, em três dimensões (3D), cujas páginas de papel se desdobram até formar casas, castelos, animais ou figuras que recriam os imaginários que compreendem qualquer mínimo detalhe.

Em cada grupo de livro infantil desta classificação, os textos constroem junto com os paratextos, e, principalmente, graças aos paratextos, imaginários que esperam a tradução e a paratradução 
do tradutor. Com a palavra "imaginário" me refiro ao conjunto de produções, mentais ou materializadas, em obras editadas, construído à base de imagens de natureza verbal no texto (imagens mentais implícitas em todo signo linguístico) e imagens de natureza não verbal no paratexto (imagens materializadas tais como desenhos, ilustrações, fotografias) que constroem estruturas coerentes e dinâmicas com um elevado valor simbólico, cujo sentido deve ser lido e interpretado corretamente para-traduzir melhor na língua e cultura de chegada esse livro infantil do qual se originou, com o objetivo principal (skopos) de editar com êxito, ou seja, adequada e apropriadamente, o livro infantil traduzido.

\section{Introdução à noção-chave da Escola de Vigo: a para- tradução}

Ninguém contestaria a importância da noção de texto em tradução, já que reconhecidamente tradutores, de fato, traduzem textos. Todavia, ressalta-se que textos não existem por si próprios. Ao contrário, para que sua presença seja uma realidade no mundo editorial, eles sempre dependerão dos paratextos. Afinal, textos existem somente para serem lidos, porém não há a possibilidade de leitura sem uma apresentação adequada do texto por seus editores, fazendo uso de diferentes produções paratextuais. A definição de "paratexto" dada por Gérard Genette, em 1982, em Palimpsestes. La Littérature au second degré, era muito sucinta, e, em 1987, o próprio Genette a retoma para dispensar ao paratexto todo a riqueza de detalhes em sua obra Seuils. Uma das principais confissões da conclusão deste último livro era que "trata-se tão somente de uma introdução e de um estímulo ao estudo do paratexto" (GENETTE, 1987, p. 407). No Grupo de Investigação Tradução \& Paratradução (T\&P) da Universidade de Vigo, aceitamos o desafio lançado à época de Genette e ultrapassamos o campo de estudo do texto literário para analisar e estudar as implicações estéticas, políticas, ideológicas, culturais e sociais de qualquer tipo de paratexto 
em tradução. Nosso objeto de estudo são todas essas produções paratextuais que não são, a princípio, consideradas como objeto de estudo da tradução, tendo em vista que não são textos propriamente ditos, mas sim paratextos. Traduzir a partir da paratradução significa dar início, muito seriamente, a argumentações sobre como as novas produções paratextuais presentes nos novos trabalhos de tradução exigem uma nova forma de traduzir: a paratradução.

$\mathrm{O}$ estudo detalhado das entidades iconotextuais, a análise minuciosa das produções verbais, icônicas e verbo-icônicas que acompanham, cercam, envolvem, introduzem e apresentam o texto de um trabalho de tradução impuseram a criação de uma nova noção nos Estudos da Tradução: a "paratradução". Houve a necessidade de uma nova terminologia tradutológica para chamar a atenção sobre a tradução do que, até então, havia ficado em segundo plano na tradutologia: os paratextos.

Para um tradutor, o texto lhe interessa por toda sua "transcendência textual", isto é, por tudo aquilo que o põe em relação com outros textos, ao que Genette designa "transtextualidade". Entretanto, Genette afirma claramente nas primeiras páginas de $\mathrm{Pa}$ limpsestes. La Littérature au second degré (1982, p. 8-16), haver cinco tipos de relações transtextuais que jamais devem confundir-se entre si, por mais que não sejam compartimentos estanques: a "intertextualidade", a "paratextualidade", a "metatextualidade", a "hipertextualidade" e a "arquitextualidade". ${ }^{9}$ A premente necessidade de estudar os paratextos em tradução que promovemos na Universidade de Vigo não se encontra, só e exclusivamente, que estes possam exercer, ou não, um importante papel na "compreensão e interpretação dos textos (NORD, 2012, p. 401). O que gostaríamos de enfatizar é que a edição final correta dos paratextos em tradução mostra-se como sendo de vital importância para a própria existência dos textos traduzidos. Desde 2005 que repetimos, à exaustão, que a principal função dos paratextos na tradução seria permitir a existência do texto traduzido ao qual acompanham, cercam, envolvem, introduzem e apresentam no mundo editorial (seja em papel ou na tela). Quando dizemos que "o texto não pode 
existir por si só", não nos referimos, absolutamente, ao "contexto" ou à "situação comunicativa" presentes, obviamente, em todo ato de cultura sempre implícito na tradução. Queremos dizer o que sempre dissemos, ou seja, pura e simplesmente não pode haver texto traduzido sem seus correspondentes paratextos paratraduzidos. Insistimos, outra vez mais, na máxima que Genette expressa de forma muito clara em suas publicações dedicadas ao paratexto: sem paratexto, o texto não existe. Um texto sem seus paratextos é invisível porque não existe no mundo editorial. Por esta razão a nossa eterna insistência na união indissolúvel que sempre existe entre o texto e seu(s) paratexto(s) correspondente(s), expressa, magistralmente, por Gérard Genette na simbólica frase: Et si le texte sans son paratexte est parfois comme un éléphant sans cornac, puissance infirme, le paratexte sans son texte est un cornac sans éléphant, parade inepte (YUSTE FRÍAS, 2012, p. 289). "E se o texto sem paratexto é, por vezes, como um elefante sem seu corna$\mathrm{ca}^{10}$, potência reduzida, o paratexto sem seu texto seria como um cornaca sem seu elefante, um espetáculo ineficaz". Um texto traduzido sem seu(s) correspondente(s) paratexto(s) paratraduzido(s) é como um elefante sem seu cornaca, isto é, "potência reduzida" porque por mais que o texto tenha sido brilhantemente traduzido, ao não existir no mundo editorial pela ausência de produção paratextual traduzida, ninguém o lerá; e um paratexto paratraduzido sem seu correspondente texto traduzido é como um cornaca sem seu elefante, ou seja, um espetáculo sem sentido, que durará enquanto for ostentado o alarde da campanha publicitária do livro, do DVD ou do videogame que se quer vender, mas que ainda não está pronto porque não se terminou de traduzir seu texto. Se as traduções são produtos compostos de textos (elefantes) e de paratextos (cornacas), esquecer qualquer um dos dois no processo de tradução pressupõe arriscar, consideravelmente, o sucesso nas vendas dos mesmos... que o elefante rompa com tudo ou que o cornaca passe por uma situação de constrangimento. Consequentemente, se, como afirma Genette (1987, p. 9-10), não há texto sem paratexto, igualmente não pode haver tradução sem a devida 
paratradução. Tradução e paratradução são sempre inseparáveis, portanto, quando se unem as duas noções que dão nome ao Grupo de Investigação de Referência (T14) que dirijo na Universidade de Vigo, emprega-se não a conjunção aditiva "e", mas o sinal, ou melhor, a ligação chamada et em espanhol, esperluette em francês, ampersand em inglês: [\&]. Esta grafia moderna do bigrama latino "et" não é, a rigor, propriamente uma "letra" do alfabeto nem um sinal de pontuação, mas sim um ideograma do traçado original de um laço, de um nó, de um desenho, de uma corda atada: um elo. No Grupo T\&P escrevemos a ligação “\&” para representar todo este sentido simbólico de união que desejamos que exista sempre entre a tradução e a paratradução. $\mathrm{O}$ objetivo principal da criação da noção de paratradução ${ }^{11}$ é o de lembrar-nos, e enfatizar, o papel essencial desempenhado pelos elementos paratextuais na tradução, ou seja, participação, juntamente com o texto, na construção do sentido do texto finalmente editado e publicado. Além disso, assim como os elementos paratextuais contribuem para estruturar a concepção e a representação de atividades tradutórias em determinada cultura editorial, a paratradução é o que faz uma tradução apresentar-se como completa no mundo editorial. Paratradução é um neologismo dos estudos da tradução que contribuiu tanto para a criação do grupo de pesquisa Tradução e Paratradução $(\mathbf{T} \& \mathbf{P})^{12}$ na Universidade de Vigo, quanto para dar início a um curso de Mestrado $^{13}$ e um programa internacional de Doutorado ${ }^{14}$ na mesma universidade. A noção foi criada, desde o início, para analisar o tempo e o espaço necessários para traduzir qualquer paratextos que cerque, envolva, acompanhe, amplie, introduza ou apresente o texto traduzido. Tudo isso foi reunido com o propósito de assegurar a existência do texto traduzido, sua recepção e consumo no mundo editorial, seja no formato tradicional de livro, ou em qualquer outra forma de publicação digitalizada (i.e., CD-ROM, DVD, e-book, videogames, websites). Na atual era da informação digital, tradutores profissionais estão cada vez mais cientes do fato de que a concepção e a regulamentação do sentido em qualquer texto podem variar conforme seus paratextos, que pode consistir de um conjunto 
particular de unidades verbais e icônicas, entidades iconotextuais ou produções materiais.

A noção de paratradução nasceu com o propósito de abordar e analisar o impacto de manipulações de cunho estético, político, ideológico, cultural e social adotadas em todas as produções paratextuais situadas dentro e fora dos limites de qualquer tradução (cf. CALLE-GRUBER \& ZAWISZA, 2000). A paratradução fornece informações sobre as atividades presentes no limiar da tradução, assim como o que representam e acrescentam em relação à subjetividade do tradutor e a natureza do produto traduzido. A paratradução contribui, igualmente, para a elucidação do papel exercido por diferentes ideologias nas relações de poder (cf. VENUTI, 1998) na distribuição e recepção das traduções.

Todavia, a noção de paratradução não se restringe somente à tradução de paratextos, mas envolve, igualmente, maior complexidade. O objetivo da paratradução é tornar-se uma referência simbólica ao espaço físico ou virtual ocupado por todas as possibilidades de produção que acompanham, cercam, envolvem, ampliam, introduzem e apresentam a tradução. Ademais, e principalmente, a paratradução tem o propósito de tornar-se uma referência simbólica para o espaço físico ou virtual ocupado por todos os profissionais de tradução no mercado real, diário. O prefixo "PARA" ajuda a designar a sempre indescritível posição da pessoa que, ao exercer a tradução, se situa ao mesmo tempo aqui e acolá da fronteira, do limiar ou da margem, com status igual ao do primeiro autor do texto que está traduzindo e, não obstante, diversas vezes aparentemente secundário, subsidiário, subordinado como estaria um convidado "diante" seu anfitrião. Um tradutor, segundo autor ante o primeiro autor, é, acima de tudo, um paratradutor, porque sua condição é a de estar ocupando sempre o espaço do prefixo "PARA"... ou seja, estar ao mesmo tempo dos dois lados da fronteira, do limiar, da margem que sempre separaram uma língua de outra, uma cultura de outra. Na verdade, o próprio tradutor é "PARA", é a fronteira em si, o próprio limiar de uma porta entre o conhecido e o desconhecido, a margem do espaço intermediário situado "entre", a 
ponte que permite o passo entre uma borda e a outra. Separa e une ao mesmo tempo. Deste modo, a noção de paratradução é ideal e apropriada para descrever e definir a hesitante e inconclusiva área espaço-temporal ocupada por tradutores que se veem frente ao exercício de traduzir tendo em mente que a qualidade do produto final dependerá das decisões tomadas de forma adequada, observando igualmente textos e paratextos. Em última análise, a paratradução permite o reconhecimento da visibilidade dos tradutores em cada e toda tradução publicadas (cf. VENUTI, 1995). Com este termo, podemos também expressar-nos, tendo em vista a necessidade de uma postura ética, política, ideológica, social e cultural do nada inocente ato de traduzir, e tudo que seja "próximo a", "por", "ao lado", "antes", "em frente", "dentro", "entre" ou mesmo "à margem da" tradução termina por ser a vida que pulsa em cada e todo texto que traduzimos. A paratradução convida o tradutor - sujeito que traduz e primeiro agente paratradutor - a ler, interpretar e paratraduzir qualquer tipo de código semiótico que cerque, envolva, acompanhe, amplie, introduza e apresente o texto às margens e nos limiares da tradução: “au seuil de la traduction” (YUSTE FRÍAS, 2010b).

Entretanto, em uma avaliação inicial, tentar propor a noção de paratradução como simplesmente "a tradução dos paratextos" não é o suficiente, pois tão pouco permitiria uma ampliação do corpus textual objeto da perspeciva tradutodógica sem realmente suscitar uma nova teorização. Para manter-se fiel à amplitude poética proposta pelo próprio Gérard Genette, seria lamentável não atribuir à noção uma extensão teórica de maior proporção que poderia ser de grande valia para os estudos da tradução. E se os estudos da tradução nunca deixaram de estar atentos às estruturas simbólicas onipresentes nas manipulações ideológicas, sociais e culturais dos processos de tradução (cf. LEFEVERE, 1992; NIRANJANA, 1992), sempre o fez a partir da perspectiva dos textos traduzidos e suas relações com os originais, utilizando tão só, e ocasionalmente, os paratextos. Por esta razão o Grupo T\&P não se conteve em somente importar do domínio disciplinar da teoria da literatura a noção de "paratexto" para aplicá-la à tradutologia. Deslocamos a 
noção de paratexto com o propósito de aplicar, de forma teórica e prática, a nova noção de paratradução em três níveis metodológicos:

1. Nível empírico: estuda os elementos paratextuais, verbais e não verbais (provenientes de códigos semióticos como o visual e o auditivo), relacionados virtual ou fisicamente com o texto a ser traduzido. $\mathrm{O}$ que requer preparar o profissional para adquirir estratégias de tradução diferentes das que está acostumado quando trabalha só e exclusivamente com o código linguístico. Seria o nível paratradutório propriamente dito.

2. Nível sociológico: estuda os agentes, as normas, os procedimentos e as instituições relacionadas com o processo tradutório e todas as fases desenvolvidas. Estaríamos em um nível protradutório.

3. Nível discursivo: estuda os discursos sobre a tradução que orientam seu funcionamento e asseguram seu papel na sociedade. Trata-se de um nível metatradutório.

Evidentemente não se trata de nenhuma novidade o estudo desses fenômenos. No Grupo T\&P é óbvio que não inventamos a roda (cf. NORD, 2012), porém a estamos fazendo percorrer caminhos até então não explorados pelos Estudos da Tradução. A novidade acerca da paratradução consiste em tentar descrever aquilo que une os três níveis mencionados acima, a fim de estruturar um posicionamento metodológico comum situado ao redor da tradução, ou melhor, em suas margens, sempre atento a tudo o que influencia ou determina o processo de tradução e que, até o momento, tenha passado despercebido ao esquema tradicional de leitura adaptada pela tradutologia tradicional que se baseia, única e exclusivamente, no texto traduzido e pouquíssimas vezes em seus paratextos. A perspectiva paratradutológica que queremos trazer aos Estudos da Tradução apresentaria o seguinte: há sempre margens nos textos, presentes em três níveis distintos, que participam ativamente no 
processo de tradução. Ademais, nossa motivação epistemológica está relacionada com a natureza do próprio ato tradutório ao encontrar sua legitimidade em um status situado à margem do original, sem que isso implique, absolutamente, em uma inferioridade, a não ser que, deliberadamente, assim seja decidido.

A noção de paratradução surgiu com o objetivo de ajudar a delinear nos Estudos da Tradução uma nova área paradigmática propícia a retomar os questionamentos sobre a prática e a teoria da tradução. Fiel à etimologia e ao sentido do prefixo grego "para-", a noção de paratradução abre novas perspectivas teóricas, didáticas e profissionais incitando à reflexão sobre tudo o que ocorre às margens do processo tradutório, no limiar da tradução. Ao revalorizar o limiar e desmarginalizar a margem em tradução, a noção de paratradução instaura essa experiência do limiar tão esquecida na concepção da tradução como ponte, passagem ou transferência entre línguas e culturas. A noção de paratradução foi criada para lembrar que a tradução não se trata somente de translatio, mas também, e, sobretudo, traductio. A translatio descreve, propriamente, um processo "passivo" que fora realizado de forma coletiva, em que a invisibilidade do tradutor o condena ao maior dos anonimatos; a traductio, em contrapartida, descreve um processo "ativo" que implica, inexoravelmente, uma responsabilidade individual na tarefa de traduzir, porque quem realiza o processo singular de traduzir um texto é esse único indivíduo que teve acesso e leu o texto graças a todos os seus paratextos.

Em todas as pesquisas do Grupo T\&P nós sempre consideramos muito seriamente as implicações ideológicas presentes no díptico translatio/traductio, porque, na realidade, estamos diante de duas palavras que nos falam não somente da história da tradução, mas também, e sobretudo, de nossa própria historicidade como tradutores. Cabe ressaltar que a palavra traductio não aparece entre as línguas românicas até o século XVI, enquanto que a palavra translatio já era conhecida desde a antiguidade latina. Estamos diante de duas palavras diferentes que expressam duas maneiras distintas de enfrentar a "transferência textual". Tal como aponta Alexis Nouss 
(2011, p. 47; 2012, p. 17), membro titular do Grupo T\&P desde a sua fundação, a translatio seria, precisamente, um "efeito" do processo de todo um maquinário da indústria de tradução, enquanto que a traductio entende-se, antes de mais nada, como uma "ação" de uma pessoa muito determinada que não é somente o elo de uma cadeia de comunicação, mas, acima de tudo, um ser humano. A translatio defende a communio porque seu objetivo principal consiste em alcançar uma identidade comum que apague as diferentes identidades, enquanto que na traductio quem ordena e comanda é a communicatio porque pretende-se suprir a necessidade de dar e receber, de realizar a troca não importa se mercadorias, bens ou mensagens, muito além de qualquer limite ou fronteira. Cultura comum (translatio) frente à cultura em comum (traductio). Antoine Berman afirma com maestria e de forma eloquente:

Enquanto a translation enfatiza o movimento de transferência ou de transporte, a traduction, por sua vez, destaca mais propriamente a energia que preside este transporte, pois remete à ductio e ducere. A traduction consiste em uma atividade que implica um agente, ao passo que a translation se definne como um movimento de passagem de caráter mais anônimo. (BERMAN, 1988, p. 31).

Porque quem traduz sempre vivencia, primeiramente, a experiência dos limiares e das margens do texto que deve traduzir (traductio) antes de decidir qualquer transferência de sentido do mesmo (translatio) após sua leitura, compreensão e interpretação, a noção de paratradução vem a ser uma ferramenta metodológica essencial ao tratar de qualquer mínimo detalhe tipográfico na edição final dos paratextos que acompanham, cercam, envolvem, introduzem e apresentam tanto o texto de partida, quanto o texto de chegada. 


\section{Uma encomenda real de tradução \& paratradução}

Em 2002 a linha editorial do grupo de lojas de brinquedos educativos Imaginarium me contactou para solicitar, com urgência, o trabalho de tradução para o espanhol de dois livros infantis escritos em francês: dans ma maison il y a... de Valérie Gerspacher ${ }^{15} \mathrm{e}$ dans ma forêt il y a... de Anne-Laure Witschger ${ }^{16}$. Explicaram-me que todas as traduções para as línguas oficiais da Espanha já haviam sido encomendadas e realizadas, mas ao analisar a revisão das amostras não ficaram satisfeitos com o resultado final de determinadas versões, entre elas a tradução para o espanhol. Como muitas vezes acontece no verdadeiro mercado de tradução profissional, a nova encomenda tinha muita pressa e me propuseram, da noite para o dia, fazer a tradução para o espanhol dos livros franceses acima mencionados para o dia seguinte, porque tudo já estaria na gráfica. Aceitei maravilhado, porém ao ter o material em mãos, 13 páginas não numeradas com um conteúdo verbal de textos que não superava duas linhas por página, em vista ao conteúdo visual que ocupava $90 \%$ da página, lhe pedi não somente um pouco mais de tempo, mas também acesso a toda a produção paratextual que cercava, envolvia, acompanhava, ampliava e apresentava o texto que me responsabilizaram por traduzir.

Diante de encomendas de tradução de livros infantis cuja introdução acabo de descrever, um neófito poderia pensar que traduzir um livro infantil é muito mais fácil, já que a quantidade de palavras é muito escassa, porque não dizer, praticamente inexistente em cada página. Imaginarium já tinha provas de que traduzir para crianças não deveria ser algo fácil. Il n'y a pas de traduction facile, pas plus la littérature pour les enfants que celle pour les adultes (CLAS, 2003, p. 1). O grande desafio do tradutor se dá pela dificuldade que envolve traduzir o par texto/imagem que constitui a essência do próprio livro infantil. O tradutor deve traduzir não somente as ideias e pensamentos do conteúdo verbal do livro infantil, mas também, e sobretudo, paratraduzir as emoções e sentimentos transmitidos pelos valores simbólicos do conteúdo visual do livro: 
formas, cores, texturas, sons, e até mesmo aromas das imagens peritextuais que fazem muito mais que simplesmente ilustrá-lo. Même les images, aussi dépouillées qu'elles soient, doivent être interprétées d'autant plus quand elles appartiennent directement à la trame textuelle (CLAS, 2003, p. 1). Se toda ilustração é de certo modo uma primeira forma de tradução, todo o visual em um livro infantil paratraduz o verbal antes de ser traduzido. Toda entidade iconotextual em tradução é uma estrutura indissolúvel de texto e imagem na qual nem o texto tem uma função "subordinada", nem a imagem uma função "ilustrativa", mas sim, ambos são coordenados em constante diálogo misto, que mistura e que se mistura.

\begin{abstract}
Palavras ou imagens não podem ser separadas de seu contexto, mas estão situadas no tempo e no espaço: em novas situações eles continuamente adquirem novos significados. Quando um livro a ser traduzido é ilustrado, as imagens trazem um novo ponto de vista. $\mathrm{O}$ visual é o contexto das palavras, e vice-versa: ao traduzir as ilustrações de um livro, é esta totalidade do verbal e do visual que é traduzida (OITTINEN, 2003, p. 132).
\end{abstract}

Quando se fala de livros infantis devería se rejeitar a denominação de "livros ilustrados" cada vez que o termo "ilustração" implicasse na relação de parceria entre texto/imagem uma hierarquia sempre a favor do texto e não da imagem. Quando se fala de ilustração nestes termos, implicitamente se está dizendo que aquilo que ilustra é inferior ao que é ilustrado e, portanto, pode ser dispensado. Para todo tradutor de textos com imagem fixa é muito desagradável o conceito de hierarquia que o obriga a escolher a matéria-prima de seu trabalho: ou o texto ou a imagem. Se desconsiderarmos a imagem em um livro infantil este já não existe como tal. A illustratio antes de fazer referência a imagens, designava as explicações e os exemplos didáticos que acompanhavam um texto: 
“ilustrar” era trazer à luz, explicar, esclarecer, divulgar, desenvolver, comentar. Um texto podia perfeitamente ilustrar outro texto. Só se poderia admitir que nos livros infantis existisse "ilustração" se fosse através de um sentido etimológico da palavra, isto é, se o termo ilustração fosse compreendido nas duas direções: caso a imagem seja suscetível a esclarecer (illustrare) o texto e o texto também possa esclarecer a imagem em um contínuo acompanhamento mútuo.

Na tradução de livros infantis o tradutor deve estar sempre consciente da estreita relação existente entre o texto e a imagem. Entretanto, muitos são os que, vez ou outra, cometem o erro crasso de pensar que na tradução especializada de textos com imagem fixa se encontram diante desta constante dicotomia que insiste em afirmar, ativa ou passivamente, que um texto não é uma imagem, nem uma imagem é um texto e que, portanto, o tradutor deve escolher onde atuar (ou no texto ou na imagem), achando, antecipadamente, que o seu é o conteúdo verbal e não o conteúdo visual, porque se supõe que só trabalha com as palavras porque estas seriam muito mais "sérias" que as imagens. Todavia, continua a acreditar que o ensino da tradução deve focar-se no conteúdo verbal da comunicação humana. Da mesma forma que não traduzimos palavras sem textos, tampouco traduzimos línguas isoladas de outros códigos semióticos, mas suas atualizações em atos de discurso únicos e irrepetíveis em plena interação intersemiótica. Considerar o imprescindível conteúdo verbal do texto não deveria nunca envolver o desprezo de todos os aspectos não verbais presentes nos paratextos. Texto e paratexto: tradução \& paratradução.

\section{Tipografia criativa para traduzir}

A TRAdução da Literatura Infantil e Juvenil (TRALIJ) não é nenhum jogo de crianças. Ao se traduzir constantemente o par texto_imagem, o tradutor trabalha imperdoavelmente com a dimensão visual e material da escrita. Quando traduzimos livros infantis, os 
tradutores temos consciência de que a dimensão gráfica do layout e a importância visual da tipografia são elementos que não só dão sentido à comunicação escrita, mas constituem a essência em si da escrita propriamente dita. O texto não é somente uma entidade linguística. Antes de ser lido, todo texto deve ser visto e para conseguir ser visto, precisa sempre expor sua visibilidade com o propósito de assegurar sua existência material na edição final. O profissional da tradução editorial está consciente da dualidade constitutiva de toda escrita. Sem nunca deixar de ser linguística, a escrita é sempre material e visual.

Para traduzir elementos paratextuais, o tradutor precisa desenvolver uma capacidade que tem sido consideravelmente ignorada em sua formação, a alfabetização Visual, a qual Oittinen (2000, 2003) define:

\begin{abstract}
Atualmente, o visual é uma questão central em vários outros ramos da tradução, assim como a tradução audiovisual e a redação técnica. Até mesmo intérpretes necessitam interpretar gestos e linguagem corporal. No entanto, frequentemente os tradutores são levados a considerar tão somente o verbal, o que seria o motivo pelo qual a alfabetização visual é negligenciada na formação do tradutor (OITTINEN, 2003, p. 139).
\end{abstract}

O aspecto visual em livros infantojuvenis não está restrito a cores e formas dos peritextos icônicos presentes na edição final publicada. Afirmações como "[o] visual é muito mais que simples palavras e ilustrações, é toda a aparência visual do livro, incluindo detalhes tais como a estrutura fraseológica e a pontuação" (OITTINEN, 2003, p. 139) devem ser levadas em consideração. O menor detalhe tipográfico torna-se como um elemento paratextual que o tradutor deve ler, interpretar e paratraduzir. A partir da perspectiva de experiência de ensino de disciplina que a antiga licenciatura em tradução e interpretação da Universidade de Vigo, denomi- 
namos Ortotipografía para traductores ${ }^{17}$ e que no atual currículo intitulamos Revisión y corrección de textos ${ }^{18}$, através da qual mostramos a nossos estudantes que as regras ortográficas e as diversas composições tipográficas presentes em um texto publicado devem sempre ser levadas em consideração ao fornecer traduções de qualidade. A tipografia correta - ou seja, a "ortografia tipográfica”, ou, melhor dizendo, a "ortotipografia" - torna-se um elemento paratextual essencial à tradução, uma vez que a tipografia de cada letra escrita, seu tamanho e seu estilo contribuem não apenas para a legibilidade da tradução, mas igualmente para o sucesso ou fracasso da apresentação desta tradução no primeiro e mais importante espaço paratextual do livro - sua capa e seu título: “Ortotipografía y traducción" (YUSTE FRÍAS, 2010a).

"Ortotipografia” é a palavra com a qual se designa a parte da ortografia técnica responsável pelo estudo e aplicação das regras de escrita tipográfica. A ortotipografia é o conjunto de regras, usos e convenções particulares com as quais se rege a correta escrita por meio de recursos tipográficos em cada língua. A ortotipografia é uma disciplina prática na qual, a partir da ortografia, o desenho editorial e os meios técnicos, se tomam decisões para que tudo se ajuste em benefício de uma correta comunicação escrita impressa. A ortotipografia é responsável pela combinação da ortografia e da tipografia e, em particular, da forma em que a primeira se aplica nas obras impressas.

[...] a ortografia tipográfica ou ortotipografia está mais relacionada com as famílias e estilos de letras; a aplicação da letra bold, itálica, em negrito, versalete, etc; as chamadas notas e citações bibliográficas; a produção e disposição de tabelas, citações textuais, poesías, obras teatrais, fórmulas, títulos ou subtítulos e demais conteúdos bibliológicos e tipográficos que vão muito além da simples escrita do texto principal (MARTÍNEZ DE SOUSA, 2004, p. 471). 
O efeito global do impacto e recepção da versão final do trabalho de um tradutor depende muito de uma paratradução boa ou ruim, dentre as diversas culturas ortotipográficas com as quais o tradutor trabalha. Ao se deparar com a tradução de um livro, todos os detalhes ortotipográficos contidos nos paratextos e no texto em si constituem aspectos visuais extremamente relevantes. Pequenos detalhes, muitos poderiam dizer. Todavia, estes detalhes ortotipográficos fazem parte do material iconotextual a ser paratraduzido, uma vez que exercem grande influência na apresentação editorial de qualquer livro, atribuindo-lhe uma dimensão estética altamente específica. Ademais, estes pequenos detalhes acabam tornando-se elementos essenciais para o ritmo da estória, ao guiar os olhos do leitor e exercer, sobre este, uma influência emocional. Ao guiar o processo de leitura e, consequentemente, de compreensão e interpretação de qualquer ato escrito, a ortotipografia cria uma imagem bem determinada para cada letra. Letras transformam-se em uma imagem e o tradutor lê, interpreta e traduz a imagem das letras. O tradutor do século XXI não deveria permitir que suas traduções se paratraduzissem em edições que não considerassem todo e qualquer detalhe ortotipográfico que sua capacidade visual tenha apercebido ao ler, interpretar e traduzir as diversas entidades iconotextuais. Para uma criança as imagens são textos e os textos são imagens. Na verdade, se a escrita em suas origens foi um pictograma antes de se transformar em letra ${ }^{19}$, para uma criança em plena fase de alfabetização, as letras de um texto de um livro infantil são, sobretudo, linhas desenhadas.

\section{Lendo e interpretando a imagem das letras nos títulos}

$\mathrm{O}$ ato de escrever é algo sempre incônico. As fontes (ou caracteres) e seu formato ainda dependem do gráfico, de sistemas ideográficos, não importa quanto a nova tecnologia tenha conseguido esquematizar a caligrafia. Apesar de pertencerem a um mesmo estilo ou família tipográfica, nem todas as letras são as mesmas. 
O aspecto visual da imagem final das letras utilizadas para a publicação de um livro traduzido constitui um elemento paratextual essencial em qualquer processo tradutório. Quando se aplicam recursos tipográficos diacríticos, os valores padrões de palavras, orações, frases, parágrafos e títulos tornam-se cruciais. Estes sinais gráficos diacríticos constituem a base de estruturas simbólicas altamente específicas ao recriar, por exemplo, o imagético saturado em edições de livros infantojuvenis. Se cuidados extras são tomados (ao se editar qualquer livro) para que não haja erros ortográficos na impressão das letras da capa ou dos títulos, quando se trata de livros infantojunvenis, qualquer pequena falha no design tipográfico pode ocasionar consequências desastrosas nas vendas da melhor das traduções.

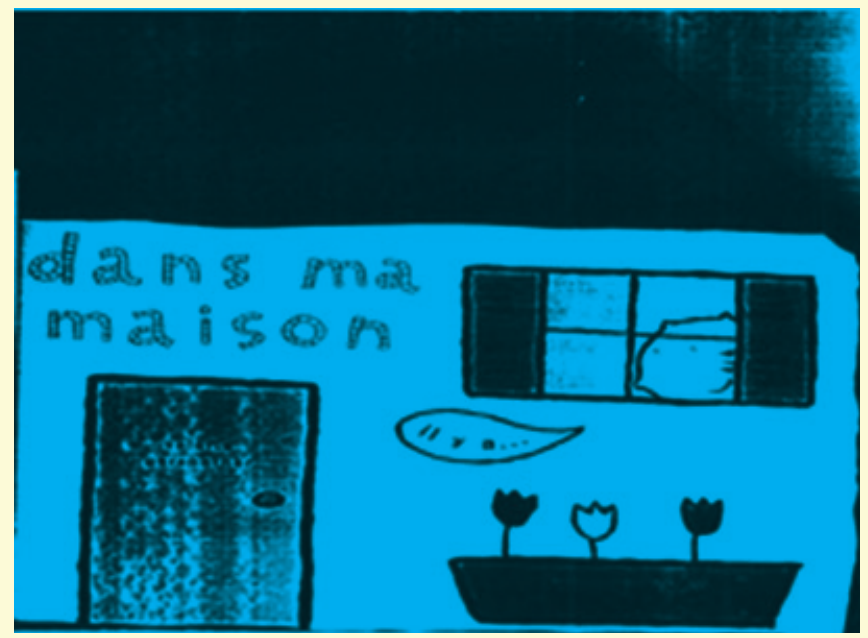

Ilustração 1

Nas primeiras edições francesas originais (GERSPACHER, 2001; WITSCHGER, 2001) dos dois livros utilizados como base para este artigo, todas as letras das palavras da primeira parte de cada um dos títulos que aparecem nas capas - dans ma maison e 
dans ma forêt - (Ilustrações 1 e 4) adotam um estilo inclinado, sem traços de união, com o intuito de simular uma escrita manual específica. $\mathrm{Na}$ verdade, as letras da capa foram impressas com caracteres de título e uma espécie de formato que parece adaptar o caracter tipográfico conhecido como itálico ou cursive ao manuscrito infantil. Isto foi feito de uma forma muito peculiar, ou seja, preenchendo o espaço de cada letra com listras, dando aos títulos um aspecto visual único. Deste modo, o projeto do título é elaborado de forma que as letras listradas sejam o primeiro elemento a atrair a atenção do olho humano que observa a capa do livro infantojuvenil, seja por uma criança ou por um adulto. Nas culturas ocidentais, superfícies listradas apresentam uma prioridade visual sobre outros tipos de superfícies, como podemos verificar com a citação a seguir:

\begin{abstract}
Em qualquer imagem, um elemento listrado será o primeiro a atrair a atenção [...] Pode-se questionar essa "prioridade visual" das listras em oposição a outras estruturas de superfície. Aquilo que é listrado pode ser visto antes de objetos conectados, junto a objetos espalhados e antes mesmo de objetos coloridos. Trata-se de um fenômeno perceptivo dos ocidentais ou seria algo comum a todas as culturas, isto é, a todos os humanos e alguns animais? Existiria algum tipo de fronteira entre biologia e cultura? E se for o caso, onde estaria tal espaço? (PASTOUREAU, 1991, p. 41-43).
\end{abstract}

Tradutores, como sujeitos tradutórios e primeiros agentes de paratradução, necessitam ser especialistas no uso de gestos, marcas, sinais, símbolos e imagens como código social da comunicação humana. Consequentemente, é óbvio que, antes que qualquer paratradução do aspecto visual de determindos elementos paratextuais seja considerada, a leitura e interpretação do material, bem como do universo simbólico das listras que figuram nas letras do título dos dois livros infantojuvenis, devem ser levados em consideração. Tudo é cultural na leitura, interpretação e tradução de qualquer ele- 
mento simbólico. Por conseguinte, seu estudo deve sempre levar em consideração seu momento histórico e o contexto exato em que o elemento aparece. Como em qualquer investigação sobre a tradução de símbolos e imagens, certos esclarecimentos semiológicos devem ser fornecidos com relação a componentes aparentemente fortuitos ou gratuitos da comunicação humana que, ao final das contas, acabam por ser essenciais à interpretação da simbologia ocidental. Somente assim, poderia ser determinado que escrever e publicar os títulos de ambos os livros com cada uma de suas letras preenchidas com listras (Ilustração 2) constitui um projeto ortotipográfico de grande valor simbólico.

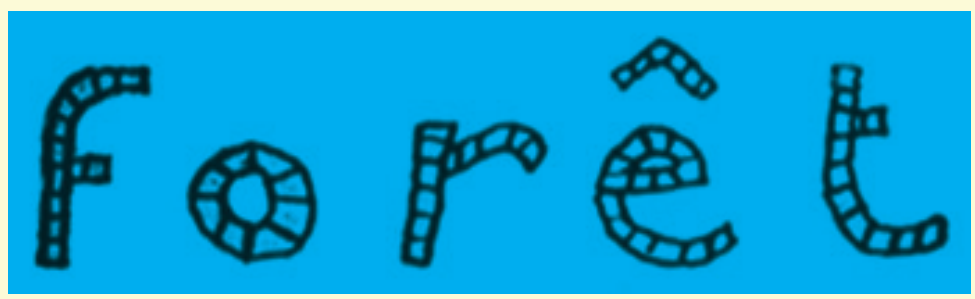

Ilustração 2

\section{Paratraduzir a simbologia das listras}

Listras são estruturas de superfícies dinâmicas que incitam movimento e dão vida a tudo que tocam, proporcionando uma propulsão infinita de energia vital. Na tradução publicitária, a capacidade paratradutória das listras é constantemente explorada: a marca Adidas conscientemente posiciona sua marca registrada, três listras paralelas e inclinadas, nas roupas esportivas que fabrica, a fim de induzir seus consumidores a acreditar que atletas que utilizam seus artefatos de três listras correriam mais rápido do que aqueles que não os utilizam ${ }^{20}$. Para o tradutor - que deve estar ciente do fato de que nenhum material publicado é tão somente 
uma visão ou percepção, mas, sobretudo, um olhar (para)tradutório bem como leitura interpretativa - as listras podem apresentar diferentes significados, dependendo do contexto da comunicação (para)tradutória.

As listras podem assumir postura "diabólica", por exemplo, quando representam a degradante marca dos exilados nos campos de concentração. Os uniformes listrados das vítimas do Holocausto constituem o tema completo do visual da roupa, que seria usado por John Boyne em seu livro para jovens adultos The Boy in the Striped Pyjamas (BOYNE, 2006); traduzido para o espanhol sob o título El niño con el pijama de rayas (tradução de Rovira Ortega, 2007); para o francês como Le garçon en pyjama rayé (tradução de Gibert, 2007); e para o português como $O$ menino do pijama listrado (tradução de Augusto Pacheco Calil, 2007). Nas edições das produções paratextuais da capa destes três livros, encontramos a paratradução das listras "diabólicas", as quais durante a Idade Média, já eram utilizadas para estigmatizar e condenar qualquer pessoa excluída da ordem social ${ }^{21}$. Desde a Idade Média, a estrutura simbólica das listras tem representado segregação ideológica e discriminação social e foi inflingida como uma infâme marca ao povo judeu (e muçulmano) na simbologia ocidental ${ }^{22}$ (PASTOUREAU, 1991, p. 29). O tão conhecido pijama listrado era a vestimenta imposta pelos nazistas a todos os exilados nos campos de concetração ${ }^{23}$. As capas das traduções mencionadas reproduzem a configuração paratextual da edição original (Ilustração 3): alternando listras azuis e brancas para escrever cada palavra dos títulos em inglês, espanhol, francês e português (The Boy / El niño / Le / O menino [listra branca] in the / con el / garçon / do [listra azul] Striped / pijama / en / pijama [listra branca] Pyjamas / de / pyjama / listrado [listra azul] rayas / rayé [listra branca]). 


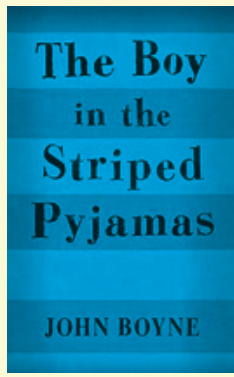

Ilustração 3-A

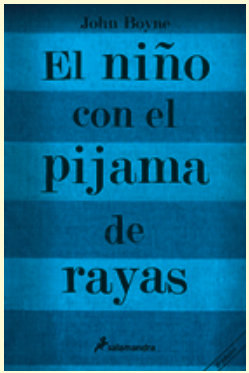

Ilustração 3-B

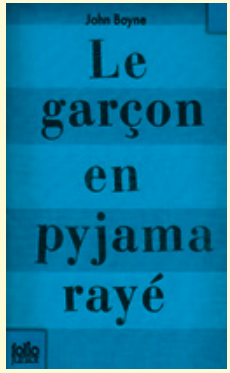

Ilustração 3-C

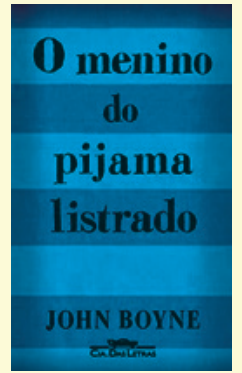

Ilustração 3-D

Porém isto não aconteceu somente em espanhol, francês ou em português. Todas as políticas editoriais de tradução do livro de John Boyne criaram em sua capa, de uma forma ou de outra, produções paratextuais baseadas em entidades iconotextuais formadas a partir de estruturas listradas para-traduzir a estrutura simbólica da listra "diabólica" da vestimenta dos campos de concentração (Ilustração 4).

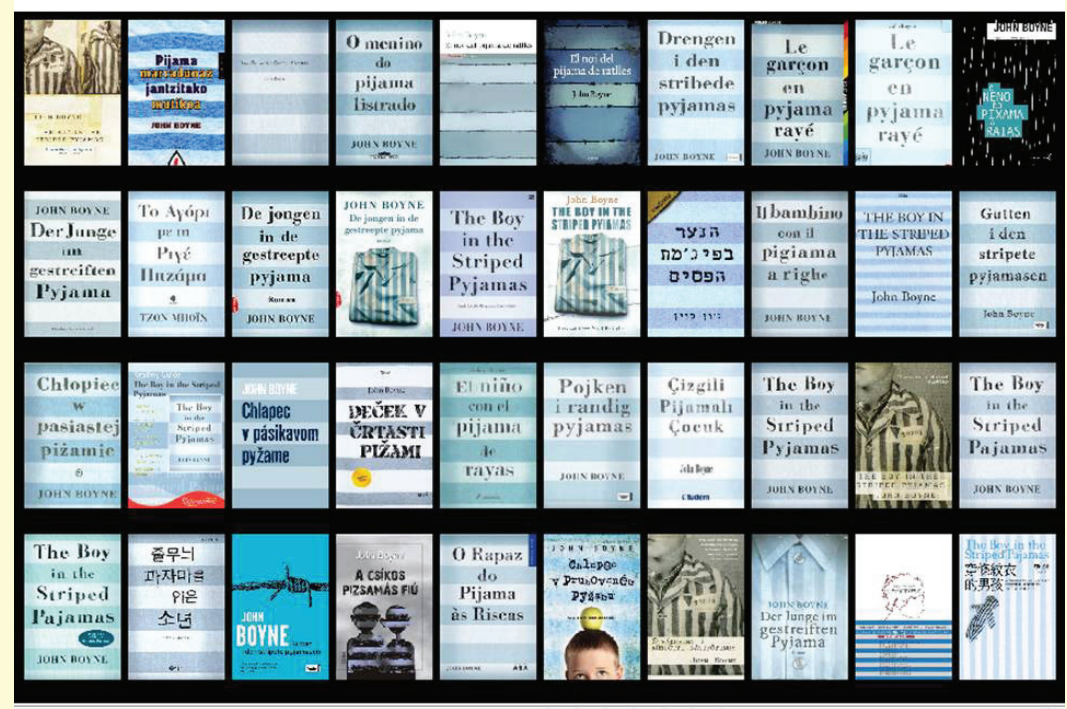

Ilustração 4

Cad. Trad., Florianópolis, $n^{0}$ 34, p. 009-060, jul./dez. 2014 
Não obstante as informações acima mencionadas, as listras podem designar outros significados simbólicos na comunicação cotidiana. Desde a criação do Grupo de Pesquisas T\&P, temos coletado inúmeros exemplos em que a estrutura das listras paratraduz mensagens altamente específicas ${ }^{24}$. Deste modo, ao dirigir nosso carro, podemos nos deparar com listras "perigosas" nas estradas - como as empregadas pelo Código de Trânsito em que, vermelho e branco indicam perigo, ou então branco e preto, que nos alerta sobre a possibilidade de pedestres atrevessarem a via, as quais, não por acaso, são denominadas como paso de cebra em espanhol, ou zebrastreifen em alemão. Como intérpretes do dia-a-dia, os tradutores também devem estar atentos à existência das listras "higiênicas", como aquelas nos lençóis que nos cobrem, nas toalhas que nos secam, ou ainda nas roupas íntimas que vestimos (c.f. PASTOUREAU, 1991). Como especialistas dos códigos sociais, tradutores devem interpretar as listras "emblemáticas" sempre que estas aparecem em uniformes, emblemas ou bandeiras.

Todavia, as listras apresentadas nos títulos dos livros infantojuvenis que estamos analisando neste artigo são dinâmicas, listras essencialmente lúdicas. Como afirma Pastoureau (1991), as relações entre a infância e as superfícies listradas remetem a longo tempo, mas as listras não adquirem este caráter positivo e essencialmente lúdico até meados do século XIX:

A relação entre crianças e listras é antiga. [...] Esperou-se quase até a segunda metade do século XIX para que esta relação entre o universo das listras e o infantil pudesse convergir. A partir de então, esta relação se consolidou [...] As listras infantis, limpas e saudáveis, e, portanto "bourgeoise", possuem igualmente um certo sentido lúdico [...] não é por acaso que o personagem Obelix, companheiro de Asterix na história em quadrinhos que leva seus nomes no título, veste enormes meias com listras verticais azuis e brancas. Este tipo de listras [...] pode ser utilizado em peças de roupa, mas também em outras superfícies relacionadas à 
infância, a festas e jogos: como doces (os berlingots franceses), brinquedos, barracas ou acessórios de circo e teatro. Atualmente, as listras infantis são completamente saudáveis e tranquilas, alegres e dinâmicas, que são as qualidades com as quais as marcas comerciais buscam basear suas vendas de produtos direcionados ao público jovem ou àquele que gostaria de se sentir mais jovem (PASTOUREAU, 1991, p. 120-126).

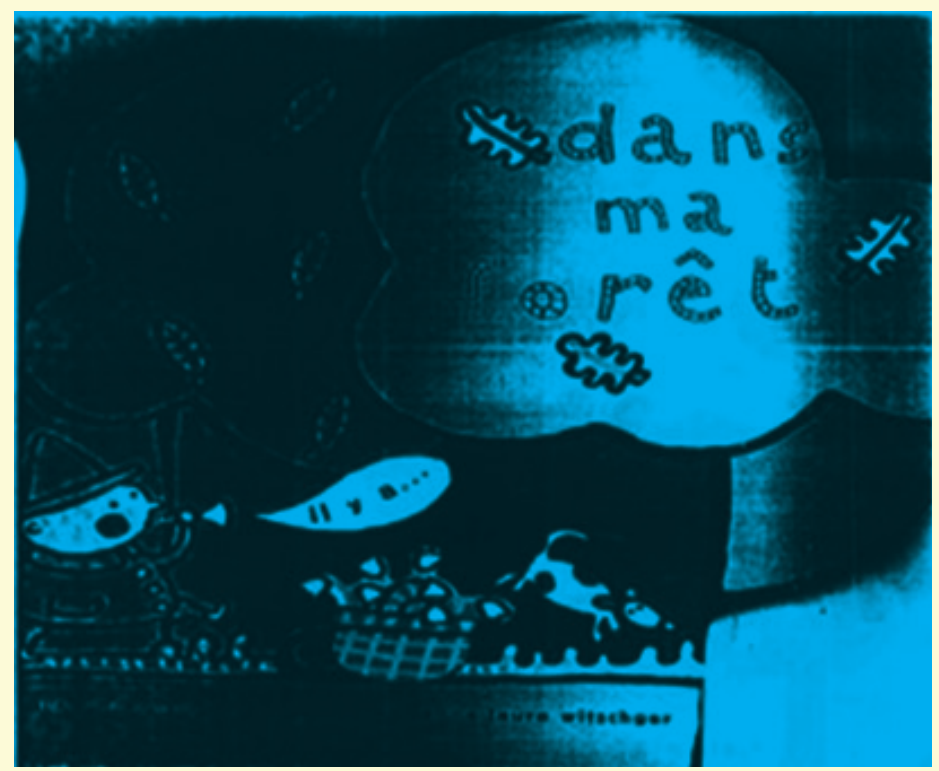

Ilustração 5

A qualidade dinâmica e lúdica instilada pelo desenho listrado proporciona certa proximidade e familiaridade com o processo da criança olhando para as capas de cada um dos livros. Um olhar primário e superficial poderia interpretar o desenho listrado das unidades iconotextuais nos títulos italizados da seguinte forma: um 
conjunto de pequenos tijolos que constroem a casa da capa do livro dans ma maison, il y a... (Ilustração 1) e, algumas trilhas ou pequenos caminhos que ajudariam alguém a encontrar seu caminho pela floresta da capa de dans ma forêt, il y a... (Ilustração 5). Um olhar secundário, bem mais profundo e atento, nos permitiria enxergar que, com o recurso das listras em cada um dos títulos das capas, um desenho foi criado. É como se a "mão" de uma criança tivesse retocado as letras criando diferentes silhuetas que se assemelham a um tabuleiro de jogo, redecorando-o ao pintar quadradinhos irregulares não numerados, com a intenção de formar pequenas quadras de amarelinha de diferentes formas (cirulares, retas, quadradas, curvadas ou em espiral) na seção geométrica de cada uma das letras.

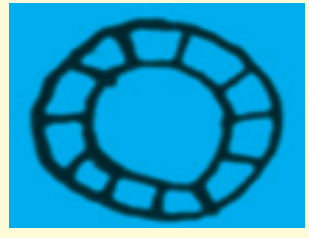

Ilustração 6-A

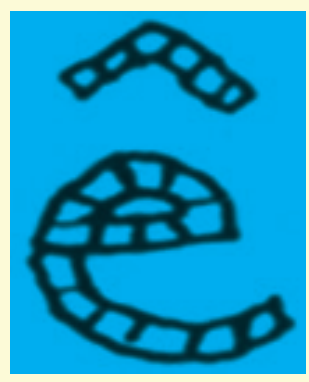

Ilustração 6-B

Desenhar quadras de amarelinha imaginárias utilizando-se de pequenas listras (Ilustração 6) - como foi feito consciente ou inconscientemente, foi o recurso adotado na apresentação tipográfica das letras na primeira parte dos títulos dos trabalhos publicados pela editora Mila Éditions - torna-se um gesto de grande valor simbólico dentro de um imaginário essencialmente lúdico, como o da infância. Como em qualquer outro jogo, o ato lúdico de desenhar as silhuetas de inúmeras quadras de amarelinha acontece em um contexto espaço-temporal muito bem determinado: o espaço e o tempo da leitura e da escrita infantil. As listras que preenchem cada uma das letras do título inicia o livro e inicia o público leitor. 
Apresentando-se na capa, estas letras configuram-se como o início físico e material do livro, bem como a iniciação do próprio público, já que o prepara - instintiva e inconscientemente - para uma das mais cruciais atividades da vida futura, a leitura e a escrita, cumprindo, deste modo, um dos mais importantes objetivos pedagógicos e educativos da literatura infantojuvenil. Listrar as letras do título desses livros configura-se, propriamente, como um ato de recreação e reconstrução de um modo essencialmente lúdico do ato de escrever, considerando-se que este pode ser visto como uma longa sucessão de listras desenhadas:

\begin{abstract}
Aquilo que é listrado não é somente algo rotulado ou classificado. Trata-se de algo relacionado ao que é criado, construído [...] como a escrita: [...] ordenar o conhecimento e o sulco fértil do pensamento e da escrita em qualquer meio, frequentemente, não é nada além do que uma extensa série de listras (PASTOUREAU, 1991, p. 144-145).
\end{abstract}

Considera-se da maior importância percebermos que nos encontramos perante uma verdadeira iniciação à leitura e escrita implementada através do desenho de diversas formas de um tradicional jogo intantil específico: a amarelinha. Trata-se de um jogo que recebe diferentes nomes de acordo com as formas geométricas utilizadas para desenhar suas quadras ${ }^{25}$, além de diferentes traduções para as línguas dos muitos países onde é jogado ${ }^{26}$. Desde os tempos remotos, os jogos têm sido atividades voluntárias e altruístas; eles se desdobram de acordo com certas regras, a fim de revelar significados simbólicos há muito esquecidos, e que são atualizados através de específicos tipos de escrita, como é este caso em questão. Os quadrados desenhados pelas alegres listras em cada uma das letras do título têm o mesmo significado simbólico que o próprio jogo de amarelinha: um percurso individual de iniciação em que cada criança vai de um nível a outro, de um quadrado ao próximo, dentro de sua própria consciência humano, dando passos através 
de um labirinto em um processo individual essencialmente lúdico. Não podemos esquecer que o jogo de amarelinha - com suas variadas formas quadradas, retangulares, circulares e espirais - tornou-se uma das representações lúdicas mais recorrentes utilizadas para "ilustrar" estórias sobre labirintos e o mito de Dédalo.

\begin{abstract}
Deste modo, o "jogo do céu e inferno", em que as crianças desenham um espiral no chão para em seguida, empurrar uma pedra e pular em um pé só, avançar por 12 casas até atingir o centro, está relacionado em sua origem, à exploração de um labirinto em cujo núcleo cada indivíduo deve descobrir o segredo de seu próprio destino e da luz sobrenatural que surge das trevas da mente inconsciente que repousa no fundo de nossas almas. [...] O jogo de amarelinha que até hoje diverte pequenas meninas, reproduzindo a experiência da jornada entre o "céu" e o "inferno", seguindo, todavia, um esquema linear em que o inferno se encontra abaixo, e o céu, acima (sem qualquer sombra de dúvida sob a influência da representação cristã do mundo), nada mais é que derivação (CAZENAVE, 1996, p. 335-336).
\end{abstract}

\title{
9. Tradução sem paratradução
}

Em resumo, o design divertido das listras preenchendo cada uma das letras do título dos referidos livros nas edições originais em francês, é incutido com toda a carga simbólica do imaginário primordial do jogo da amarelinha. A interpretação simbólica final das divertidas listras envolve a perfeita simbiose entre as duas leituras realizadas pelos primeiro e segundo olhares anteriormente mencionados. A referência simbólica do jogo da amarelinha auxilia a criança a encontrar seu caminho no espaço externo: o possível percurso labiríntico com o qual criança pode vir a se deparar ao cruzar a floresta (Ilustração 4). Ademais, a representação do jogo da amarelinha colabora para 
a verticalidade da construção poética do mais íntimo espaço infantil: sua própria casa, seu lar (Ilustração 1).

Não obstante a discussão apresentada, a editora pertencente ao grupo Imaginarium manteve apenas o uso de letras minúsculas e decidiu publicar as primeiras edições da tradução para o espanhol dos títulos mencionados (trad. de YUSTE FRÍAS 2002a; 2002b) fazendo uso de letras arredondadas em negrito (Ilustração 6 e 7). Apesar de preservar a característica arredondada e as minúsculas iniciais na edição original, descobrimos uma fonte muito mais comum na versão espanhola que salienta em sua capa de forma unívoca, a linearidade de uma escrita tipográfica nada lúdica ou infantil. O novo e imposto aspecto visual rompe com a unidade iconotextual original, distanciando, assim, imagem e texto na tradução espanhola.
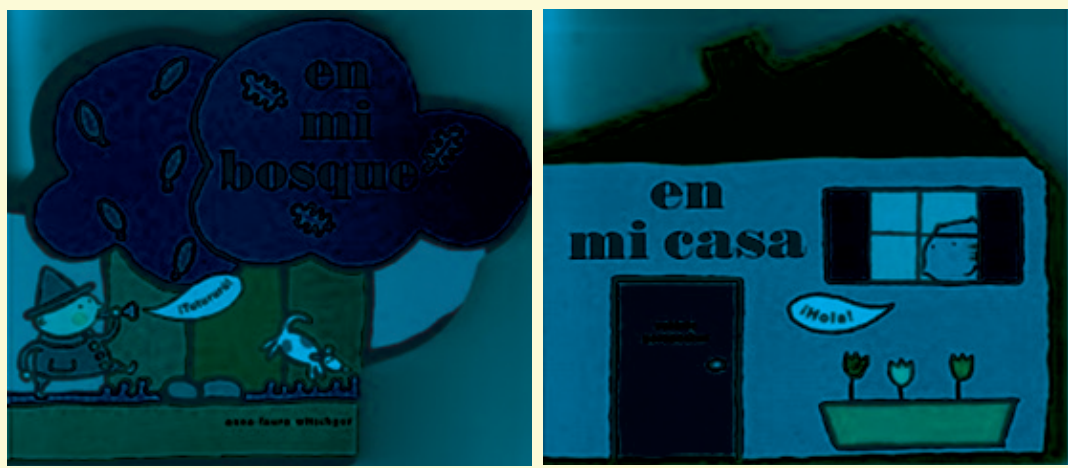

Ilustração 7

Ilustração 8

O tradutor executou a leitura e interpretação visual, porém os editores não paratraduziram o elemento visual. Não há paratradução da diacrisis tipográfica (isto é, não houve tradução adequada, atribuindo o devido valor à unidade gráfica) que tenha sido, de fato, interpretada durante o processo tradutório. A fim de apresentar o melhor em tradução, o paratexto das capas dos originais francesas requereriam uma paratradução mais cuidadosa que transmitisse o 
conjunto de implicações simbólicas do design listrado e brincalhão das letras do título. Se dizemos que não pode haver tradução sem paratradução, na edição final da tradução de nossos livros infantis, faz-se necessário paratraduzir bem o visual para traduzir melhor o verbal. Portanto, o diálogo ou negociação entre o tradutor e o editor torna-se de extrema importância a fim de atingir o principal objetivo de qualquer processo de mediação paratextual: sempre publicar traduções com suas respectivas paratraduções.

\section{Conclusões}

A paratextualidade em TRALIJ outorga formatos físicos muito específicos a determinadas produções do mercado editorial da LIJ. De fato, no livro infantil, por exemplo, os paratextos chegam a ser muito mais importantes que o próprio texto, ao ponto de ocupar mais de $90 \%$ do layout final. O livro infantil trata-se mais de um formato editorial do que um gênero literário. Para-traduzir livros infantis é indispensável desenvolver uma capacidade visual formada a partir de conhecimentos sociológicos e antropológicos básicos sobre como funciona, por exemplo, a simbologia de determinadas formas simbólicas da imagem das letras (como as listras estudadas nesta publicação) ou a simbologia das cores com as quais se editam em cada cultura as entidades iconotextuais que os tradutores têm que traduzir. Para garantir o sucesso de uma tradução, os tradutores devem ler e interpretar todo e quaisquer elementos textuais e paratextuais que compõem a imagem do trabalho a ser traduzido: as palavras, imagens, sons, movimentos, e até mesmo, no caso dos livros infantis, aromas presentes em cada texto e paratexto. Tradutores de literatura infantojunvenil traduzem textos e paratraduzem paratextos com a futura interação da criança e do adulto com a totalidade de material iconotextual que ambos estão recriando em mente. Com efeito, tradutores de literatura infantojuvenil deveriam ser reconhecidos como segundos autores, tanto do aspecto verbal quanto do visual. 
Tradutores necessitam paratraduzir paratextos bem, a fim de melhor traduzir o texto. Estar ciente da paratradução pode aumentar a conscientização dos tradutores a respeito da manipulação editorial que empobrece a maioria dos conteúdos eliminando a leitura, interpretação, e a paratradução de estruturas simbólicas do imagético dos paratextos paratraduzidos da publicação final de seus textos traduzidos. A edição de elementos paratextuais na publicação final trazem implicações não somente simbólicas, mas igualmente ideológicas, políticas, sociais e culturais. Deste modo, o fato é que - para os tradutores - o conceito de paratradução pode soar como adequado, ao tentar descrever e definir a imprecisa e indecisa zona no tempo de tradução, bem como no espaço editorial, nos quais os profissionais de tradução se encontram quando seu trabalho está, finalmente, prester a ser publicado. A possibilidade de tomar decisões juntamente com o editor interfere na qualidade do produto final. Graças à noção de paratradução, os tradutores podem reivindicar, de uma vez por todas, sua visibilidade no espaço físico e material do livro. Sendo assim, considerando-se que eles seriam segundos autores, os nomes dos tradutores deveriam aparecer não somente na página de direitos autorais, mas igualmente no frontispício e até mesmo - e porque não? - na capa do livro, próximo ao nome do primeiro autor, em pé de igualdade com este, como já vem sendo feito com os nomes do autor e do ilustrador em literaturas infantojuvenis. Esta visibilidade poria fim à ingênua impressão que a maioria dos leitores tem de terem lido tais e tais autores em francês, inglês, alemão ou italiano quando, na verdade, leram um texto escrito por um autor cujo nome eles sequer lembrarão porque o esconderijo marginal onde o editor o colocou - o paratexto da página de direitos autorais - não é, frequentemente, um lugar visitado quando se lê um livro.

A novidade da noção de paratradução nos Estudos da Tradução está em aceitar, de uma vez por todas, uma ética do limiar que oriente a prática tradutória. Vivenciar a experiência do limiar às margens do texto convida a uma forma de tradução que não consista somente em uma translatio, em uma mera passagem de uma 
língua-cultura a outra, mas sim em um genuíno deslocamento a partir das margens para uma verdadeira mudança sempre implícita em toda autêntica travessia. A partir da perspectiva da paratradução, a traductio não somente se inicia às margens, mas se encontra nas margens do texto, de fato, a tradução está sempre à margem porque traduzir implica, inevitavelmente, viver a ambiguidade da margem, a indecisão que se instaura sempre entre uma língua-cultura e outra, entre o aqui e o ali, entre o texto de partida e o texto traduzido. Contrariando todas as teorias de tradução que, até agora, continuam a intensificar a importância de um perante o outro, a postura paratradutológica incita a considerar tudo o que os enquadra e os ultrapassa com a finalidade de equilibrar as respectivas demandas socioculturais, políticas e ideológicas. A tradução é, em sua essência, paratextual. A afinidade entre tradução e paratextualidade existe porque traduzir implica, sempre, não somente por-se à margem com respeito à sua própria língua e sua própria cultura para poder acolher as do outro texto, como também, criar uma margem diante deste para que não se imponha seu total domínio.

\section{Agradecimentos}

Eu gostaria de agradecer publicamente a Gisele Tyba Mayrink Orgado pelo seu trabalho na tradução entre o inglês, o espanhol e o português brasileiro dos textos e paratextos deste artigo redigido originalmente em espanhol, francês e inglês; e a Ronaldo Lima pelo seu trabalho nas pontuais traduções entre o francês e o português brasileiro. 


\section{Notas}

1. Esta é uma versão ampliada do artigo que foi publicado em YUSTE FRÍAS, José. Paratextual Elements in Translation: Paratranslating Titles in Children's Literature. In: Gil-Bajardí, Anna, Pilar Orero \& Sara Rovira-Esteva (eds.) Translation Peripheries. Paratextual Elements in Translation. Frankfurt am Main, Berlin, Bern, Bruxelles, New York, Oxford, Wien: Peter Lang, p.117-134, 2012.

2. Foi em 1978 que a Société Française de Littérature Comparée publicou seu famoso número especial 3-4 intitulado La littérature d'enfance et de jeunesse.

3. [NDT: Todas essas obras foram traduzidas para a variante brasileira do português por Monteiro Lobato].

4. Visite o website português <http://rikerok.com/> Último acesso em: 04 de Outubro de 2014.

\section{Ibidem em: < http://www.clubrikrok.com/ >}

\section{Ibidem em: < http://www.clubrikrok.fr/>}

7. Veja, arranhe, e "sinta o cheiro". (BARDY \& DOINET, 2001).

8. Com relação à distribuição de livros infantis em diferentes espaços nas bibliotecas/livrarias, não só é curioso como também esclarecedor que, apesar de serem divulgados e vendidos on-line, os livros publicados pela editora Imaginarium só possam ser olhados e folheados em um espaço epitextual muito específico e único: as próprias lojas de brinquedos Imaginarium.

9. Il me semble aujourd'hui (13 octobre 1981) percevoir cinq types de relations transtextuelles, que j'énumérerai dans un ordre approximativement croissant d'abstraction, d'implication et de globalité. (GENETTE, 1982, p.8)

10. [NDT : Cornaca: aquele que guia elefantes e deles cuida. Fonte: Novo Dicionário Aurélio da Língua Portuguesa]. 
11. Para as condições acadêmicas da criação da noção de paratradução em Vigo, e uma visão geral de suas diferentes aplicações práticas no campo dos Estudos da Tradução ver Yuste Frías, 2010b.

12. Para maiores informações a respeito do grupo de pesquisa $\mathbf{T} \& \mathbf{P}$, criado em Março de 2005, visite < http://www.paratraduccion.com > Último acesso em: 04 de Outubro de 2014.

13. Consulte sua página web em: http://paratraduccion.com/limiares/

14. Consulte sua página web em: http://www.paratraduccion.com/index.php/ doctorado-typ.html

15. Um excerto paratextual (capa, contracapa, frontispício e folha de rosto) da primeira edição de minha tradução para o espanhol, publicada em 2002 por Imaginarium, pode ser consultada, em cores, on-line: <http://joseyustefrias.com/ docu/publicaciones/traducciones/2002a/JoseYusteFrias\%202002a.pdf >

16. Ibidem: < http://joseyustefrias.com/docu/publicaciones/traducciones/2002b/ JoseYusteFrias \%202002b.pdf $>$

17. O programa detalhado da disciplina Ortotipografía para traductores encontra-se disponível em: < http://www.joseyustefrias.com/docu/docencia/OrtotipografiaJoseYUSTEFRIAS.pdf $>$

18. Consulte a página do professor da disciplina Revisión y corrección de textos em: <https://www.facebook.com/galeradas $>$

19. Muito antes de ser o que são, as letras foram imagens. Como já se sabe, a palavra "alfabeto" foi criada a partir do hebraico álef e bet que representavam, respectivamente, em suas antigas grafias, provenientes de hieróglifos egípcios, uma cabeça de touro (ao contrário) e uma casa em cujos traços é possível ver nossa atual letra "b" deitada.

20. La marque d'articles de sport Adidas ne s'y est pas trompée, qui a choisi pour emblème trois bandes parallèles, formant comme des rayures sur les vêtements et les chaussures quelle vend un peu partout dans le monde. Ces trois bandes 
connotent pleinement l'idée de la rapidité et de performance sportive. (PASTOUREAU, 1991, p. 149-150).

21. Dès avant l'an mille, en effet, l'image occidentale a pris l'habitude de réserver un statut péjoratif à la rayure du vêtement [...] Dans l'image comme dans la rue, sont ainsi fréquemment signalés par un vêtement ou un attribut rayé tous ceux qui se placent hors de l'ordre social, soit en raison d'une condamnation (faussaires, faux monnayeurs, parjures, criminels), soit en raison d'une infirmité (lépreux, cagots, simples d'esprit, fous) soit parce qu'ils exercent une activité inférieure (valets, servantes) [...] soit parce qu'ils ne sont pas ou plus chrétiens (musulmans, juifs, hérétiques). Tous ces individus transgressent l'ordre social, comme la rayure transgresse l'ordre chromatique et vestimentaire. (PASTOUREAU, 1991, p. 31-33).

22. Le rayé, quels que soient son périmètre et ses couleurs, est plus fortement marqué - et donc plus 'efficace' - que la couleur jaune, le bonnet pointu ou la rouelle partie. (PASTOUREAU, 1991, p. 29).

23. O pijama listrado no qual o correspondente triângulo ou estrela de David foi costurado, estigmatizando a hierarquia racista e social estabelecida pelos nazistas: um triângulo azul para exilados apátridas; um triângulo marrom para exilados ciganos; um triângulo preto para exilados sem sociedade; um triângulo vermelho para exilados políticos; um triângulo rosa para exilados homossexuais; um triângulo verde para exilados de direito comum; um triângulo roxo para sectaristas bíblicos; um triângulo amarelo e uma estrela vermelha para exilados da resistência judaica.

24. Veja os três capítulos dedicados à tradução intersemiótica da simbologia das listras publicado em EXIT < http://www.joseyustefrias.com/index.php/web-tv/ exit.html > (último acesso em 04 de Outubro de 2014), o segundo programa de Web-TV do Grupo T\&P.

25. O jogo de amarelinha é conhecido na Galícia por diversos nomes como: rollo, mariola, cotelo, truco, roleta, peletre, e um extenso etcetera. Muitos desses nomes foram atribuídos de acordo com a forma geométrica utilizada para desenhar a quadra do jogo. Justifica-se, assim, a variedade de nomes galegos para designar este jogo: o forte da colina (o castro, o castrillo), o mundo (o mundo), o caracol (o caracol), o guarda-roupa (o armario), o jogo do boné (o xogo da chapa, a chapa de nove, a chapa chinesa, a chapa do aeroplano), o boneco e a boneca (o boneco e a boneca), os meses (os meses do ano), o jogo transatlântico (o transatlántico), e, naturalmente, o céu a e terra (o ceo e a terra). 
26. Assim, temos nomes como: calajanso, calderón, cascayu, coroza, coxcox, coxcojilla, cruceta, chinche, escanchuela, futi, infernáculo, monet, palet, pata coja, pico, pique, pitajuelo, rayuela, reina mora, tejo, teta, toldas, trillo, truco, truquemele, xarranca na Espanha; jogo do homen, jogo da mulher, macaca, da macaca, do diablo, do homen morto, da gargalo, da cuadrado, do truque, pulgarcillo em Portugal; aeroplano, gambeta, luche, lucho, rayuela, tejo, tilín, tuncuna na Argentina; coxcojilla, luche, lucho, mariola, tejo no Chile; la golosa, coroza, na Colombia; tejopijeje no México; mundo, changala no Peru; peregrina, trúcamelo na República Dominicana; la grulla, la vieja na Venezuela; Munzenivurspiel, Hinspiel, Himer an hollé na Alemanha; hopscotch na Austrália, Estados Unidos e Reino Unido; hinkelen na Holanda; marelle na França; e assim por diante [NDT: No Brasil, além de jogar amarelinha, a brincadeira é também conhecida por academia, pular macaca, pular maré, avião ou sapata].

\section{Referências}

BARDY, S. ; DOINET, M. Où est la crotte de Paco? Gratte et découvre les odeurs dans la maison. Paris: Le petit musc-Play Bac, 2001.

BERMAN, A. De la translation à la traduction. In: TTR: traduction, terminologie, rédaction, v. 1, n. 1, p. 23-40, 1988,. Disponível em: < http://www.erudit. org/revue/ttr/1988/v1/n1/037002ar.pdf $>$. Acesso em: 01 ago. 2014.

BOYNE, J. The Boy in the Striped Pyjamas. Oxford: David Fickling Books, 2006.

. El niño con el pijama de rayas. Tradução de Rovira Ortega. Barcelona: Salamandra, 2007.

CALLE-GRUBER, M.; ZAWISZA, E. (Ed.). Paratextes. Études au bord du texte. Paris: L'Harmattan, 2000. 
CAZENAVE, M. (Dir.) Encyclopédie des symboles. Paris: Le Livre de Poche, 1996.

CLAS, A. Editorial. In: Meta, v. 48, n. 1-2, 2003, p. 1. (Volume dedicado a Traduction pour les enfants y dirigido por Riitta Oittinen). Publicação disponível on-line: < http://www.erudit.org/revue/meta/2003/v48/n1/006952ar.pdf > . Acesso em: 01 ago. 2014.

COLIN, M. La Littérature d'enfance et de jeunesse en France et en Italie au $\mathrm{XIX}^{\mathrm{e}}$ siècle: traductions et influences. In: Chroniques italiennes. v. 30, n. 2, p. 1-70, 1992, Disponível em: < http://chroniquesitaliennes.univ-paris3.fr/PDF/30/ Colin.pdf >. Acesso em: 01 ago. 2014.

GENETTE, G. Palimpsestes. La Littérature au second degré. Paris: Seuil, 1982. . Seuils. Paris: Seuil, 1987.

GERSPACHER, V. Dans ma maison, il y a.... Paris: Mila, 2001.

. En mi casa. Tradução de José Yuste Frías. Zaragoza: Imaginarium, 2002a. Excertos paratextuais do livro disponíveis na página de internet do autor: < http://joseyustefrias.com/docu/publicaciones/traducciones/2002a/JoseYusteFrias \%202002a.pdf >

GRÉGOIRE, M.-H. \& QUATRE FLEUVES L'étoile de Mimosa. Livre oreiller tout doux. Paris: Quatre Fleuves, 2001.

LEFEVERE, A. Translation, Rewriting and the Manipulation of Literary Frame. London and New York: Routledge, 1992.

MARTÍNEZ DE SOUSA, J. Ortografía y ortotipografía del español actual. Gijón: Trea, 2004.

NIRANJANA, T. Siting Translation. History, Post-structuralism and the Colonial Context. Berkeley/Los Angeles/Oxford: University of California Press, 1992. 
NORD, C. Paratranslation - a new paradigm or a re-invented whell?. In: Perspectives: Studies in Translatology, v. 20, n. 4, p. 399-409, 2012.

NOUSS, A. La traduction : au seuil. In : De Dampierre, E. ; Metzger, A-L. ; \& Poulin, I. (Ed.) Traduction et partages : que pensons-nous devoir transmettre ?. Livro publicado após o XXXVII Congresso da SFLGC (Société Française de Littérature Générale et Comparée). Borgonha : Université Bordeaux Montaigne, 2011, p. 46-64. Capítulo do livro disponível em : < http://vox-poetica.com/sflgc/ actes/traduction/2.1.\%20Nouss.pdf > . Acesso em: 01 ago. 2014.

. A tradução: no limiar. In: Alea, v. 14, n. 1, 2012, p. 13-34. Disponível em: <http://www.scielo.br/pdf/alea/v14n1/v14n1a02.pdf > . Acesso em: 01 ago. 2014.

OITTINEN, R. Translating for Children. New York-Londres: Garland Publishing, 2000.

. Where the Things Are: Translating Picture Books. In: Meta, v. 48, n. 1-2, 2003, p. 128-141. (Volume dedicado a Traduction pour les enfants e dirigido por Riitta Oittinen). Disponível em:<http://www.erudit.org/revue/meta/2003/ v48/n1/006962ar.pdf. Acesso em: 01 ago. 2014.

PASTOUREAU, M. L'étoffe du Diable. Une histoire des rayures et des tissus rayés. Paris: Seuil, 1991. Coleção La librairie du Xxe siècle.

PERROT, J. Recherche et littérature de jeunesse en France. Recherche pure ou appliquée ? In: Bulletin des Bibliothèques de France (BBF), v. 44, n. 3, p. 13-24, 1999. Disponível em: < http://bbf.enssib.fr/consulter/02-perrot.pdf $>$. Acesso em: 01 ago. 2014.

SHAVIT, Z. The Concept of Childhood and Children's Folktales: Test Case: 'Little Red Riding Hood'. In: DUNDES, A. (Ed.), Little Red Riding Hood: A Casebook. Madison, Wisconsin e Londres: The University of Wisconsin Press, 1989. p. 129-159.

. Beyond the Restrictive Frameworks of the Past: Semiotics of Children's Literature - A New Perspective for the Study of the Field. In: Ewers H.-H., Lehnert, G. \& O’Sullivan, E. (Ed.), Kinderliteratur im interkulturellen Prozeß. 
Studien zur Allgemeinen und Vergleichenden Kinderliteraturwissenschaft. Stuttgart: Metzler, 1994. p. 3-15.

. Cheshire Puss,... Would you tell me, please, which way I ought to go from here? Research of Children's Literature - The State of the Art. How did we get there - how should we proceed. In: Fernández Vázquez, J. A., Labra CeNitagoya, A. I. \& Laso León, E. (Ed.), Realismo Social y Mundos Imaginarios: Una Convivencia para el Siglo XXI. Madrid: Universidad Alcala, 2003.p. 30-41.

VENUTI, L. The Translator's Invisibility. A History of Translation. Londres/ New-York: Routledge, 1995.

Scandals of Translation: Towards an Ethic of Difference. Londres/ New-York: Routledge, 1998.

WITSCHGER, A. L. Dans ma forêt, il y a.... Paris: Mila, 2001.

. En mi bosque. Tradução de José Yuste Frías. Zaragoza: Imaginarium, 2002b. Excertos paratextuais do livro disponíveis na página de internet do autor: $<$ http://joseyustefrias.com/docu/publicaciones/traducciones/2002b/JoseYusteFrias\%202002b.pdf > . Acesso em: 01 ago. 2014.

YUSTE FRÍAS, J. Puer senex: l'enfant aux trois dons. Textos, 1993, p. 15-27. Disponível on-line: <http://joseyustefrias.com/docu/publicaciones/JoseYusteFrias\%201993.pdf > . Acesso em: 01 ago. 2014.

Ortotipografía y traducción. In: YUSTE FRIAS, J. (Dir.) Píldoras

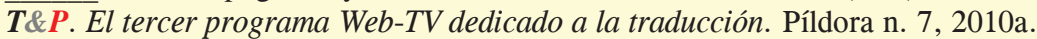
Editada on-line em 10/06/2010. Apresentação desta produção audiovisual T\&P disponível na página de internet do autor: <http://www.joseyustefrias.com/index.php/web-tv/pildorastyp/57-pildoras/142-ortotipografia-y-traduccion.html > . Apresentação do programa Web-TV Píldoras $\boldsymbol{T} \& \boldsymbol{P}$ também disponível na página de internet do autor: <http://ww.joseyustefrias.com/jyuste/index.php/web-tv/ pildorastyp.html > . Acesso em: 01 ago. 2014.

. Au seuil de la traduction: la paratraduction. In: NAAIJKENS, T. (Ed.)

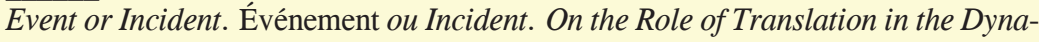
mics of Cultural Exchange. Du rôle des traductions dans les processus d'échanges 
culturels. Bern, Berlin, Bruxelles, Frankfurt am Main, New York, Oxford, Wien: Peter Lang, 2010b. Coleção Genèses de Textes-Textgenesen. Françoise Lartillot (Dir.), v. 3, p. 287-316. Informações detalhadas sobre a publicação disponíveis na página de internet do autor: < http://www.joseyustefrias.com/index.php/publicaciones/prueba-libros/64-informacion-detallada/174-au-seuil-de-la-traduction-la-paratraduction.html >. Acesso em: 01 ago. 2014.

Recebido: $15-08-14$

Aceito: 25-09-14 